\title{
El arte de la crítica: Rubén Darío y sus crónicas desconocidas del Salón de 1895 para La Prensa
}

\author{
Rodrigo Javier CARESANI \\ CONICET-Universidad de Buenos Aires \\ rjcaresani@filo.uba.ar
}

\begin{abstract}
RESUMEN
Bajo el impulso que ha llevado a los estudios recientes sobre el modernismo latinoamericano a reevaluar el sentido de los flujos culturales desde las capitales de la modernidad hacia sus periferias -desestimando categorías como las de "influencia", "exotismo" y "torremarfilismo", estereotipos que por décadas nublaron la comprensión crítica de esta estética-, el presente trabajo se propone indagar una práctica persistente en los principales escritores del movimiento. Se trata de la crítica pictórica modernista, género que abordamos a partir del análisis de un corpus poco conocido, las siete crónicas que Rubén Darío publica en el diario La Prensa a propósito de la tercera exposición de arte del Ateneo de Buenos Aires. Nuestra hipótesis propone que los raros creadores de imágenes retratados por Darío a fines de 1895 funcionan como contrapunto visual de las semblanzas de escritores excéntricos que un año después integran el fundamental volumen Los raros (1896). En este temprano "salón", que reproducimos completo acompañado de notas explicativas, el poeta faro del modernismo ensaya y consolida su apuesta transculturadora de la tradición universal -ahora aplicada a los Salones (1845-1859) de Charles Baudelaire y al monumental proyecto de John Ruskin en Los pintores modernos (1843-1860)- para legitimar desde otro subgénero de la crónica modernista una nueva figura de crítico-escritor, en disidencia con el modelo iluminista del "letrado".
\end{abstract}

Palabras clave: Modernismo hispanoamericano, crónica, salón, écfrasis, crítica artística.

The Art of Criticism: Rubén Darío and his Unknown Chronicles of the 1895 Salon for La Prensa

\begin{abstract}
With the impetus that has led recent studies on Latin American Modernism to a reevaluation of the sense of cultural fluxes from the modernity capitals to its peripheries - discarding categories such as "influence", "exotism" and "ivory tower", stereotypes that have clouded critical understanding of this aesthetics for decades- the present study intends to investigate a persistent practice of the main writers of the movement. This practice is modernist pictorial criticism, a genre that will be approached through the analysis of an unknown corpus: the seven chronicles Rubén Darío published in the journal La Prensa on occasion of the third art exposition of the Ateneo de Buenos Aires. Our hypothesis is that the rare creators of images portrayed by Darío by the end of 1895 work as a visual counterpoint of
\end{abstract}


the eccentric writers' biographical sketches that a year later will be part of the fundamental volume Los raros (1896). In this early "salon", which we reproduce in its entirety, accompanied by explanatory notes, the leader of Modernism rehearses and consolidates his transcultural work with the universal tradition -now applied to the Salons (1845-1860) by Charles Baudelaire and to the monumental project by John Ruskin in Modern painters (1843-1860)- to legitimate, from another subgenre of Modernist criticism, a new figure of the critic, in dissent with the Enlightenment model of the writer.

Key words: Spanish American Modernism, chronicle, salon, ekphrasis, art criticism.

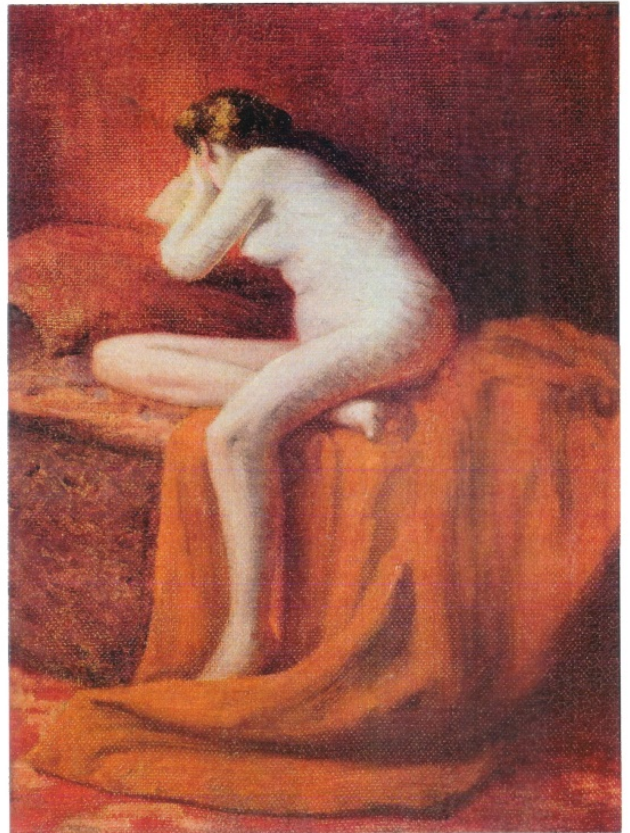

Eduardo Schiaffino. Desnudo. Sinfonía en rojo, 1895. Buenos Aires. Óleo sobre tela. Colección del Museo Nacional de Bellas Artes (Buenos Aires)

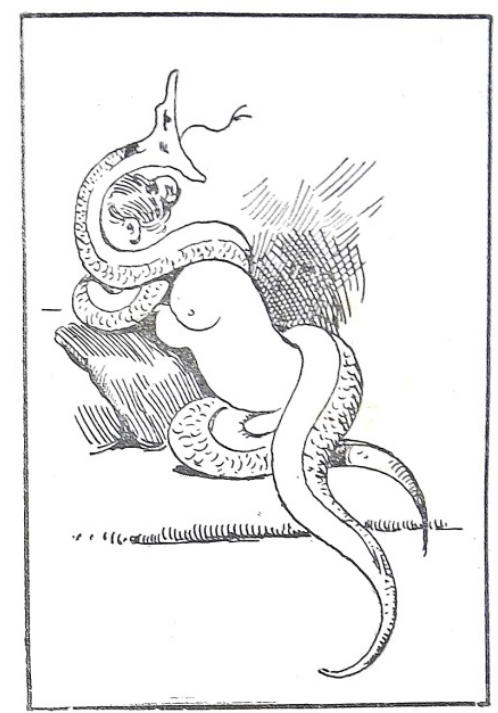

85.-Schiaffino-Las serpientes, sinfonía en punta. (Nota profana).

Manuel Mayol. "El Salón cómico". Revista semanal ilustrada. Año I, $\mathrm{N}^{\circ} 30$, 27 de octubre de 1895, p. 10.

\section{El modernismo y la crítica artística en el fin de siglo}

El estudio de la relación entre literatura y otras artes en la estética del modernismo aparece como un fecundo objeto de indagación si se atiende al panorama actual de la bibliografía especializada. Iván Schulman, investigador dedicado desde hace décadas a este vínculo, anunciaba en un ensayo reciente que el análisis de la "indiscutible relación con otros discursos artísticos" llevaría a las lecturas contemporáneas a "modificar nuestro concepto del modernismo 
hispanoamericano" (2013: 23). No resulta exagerado sostener que esa modificación o ampliación, aunque lejos de acabada, se ha sustanciado en un abanico plural de aproximaciones al fin de siglo, cada una de ellas bajo supuestos teóricos propios y muchas veces acompañadas de sofisticados dispositivos metodológicos. Pero además, la complejidad de la cuestión parece reclamar la intervención de saberes provenientes de disciplinas vecinas a los estudios literarios. Sólo por ilustrar la variedad, si los acercamientos de Laura Malosetti Costa (2001) y Alfonso García Morales (2004) constituyen exponentes destacados de una línea asimilable a la historia del arte, análisis como los de Alejandra Laera (2007) y Federico Bibbó (2014) -enfocados en las instituciones culturales y los vínculos sociales entre pintores, poetas y músicos- encuentran su horizonte de validación en la perspectiva de una sociología de la cultura. En el terreno de la crítica literaria, las conexiones entre artes en la escritura modernista están siendo reevaluadas desde categorías como "transcodificación" (Tinajero 2004), "tecnologías del espectáculo" (González Stephan y Andermann 2006), "democratización" y "cultura del consumo" (Montaldo 2007), "intersemioticidad" (Caresani 2014) o "intermedialidad" (Torres 2014), entre muchas otras. Sin ánimo de agotar el estado de la discusión contemporánea sobre el fenómeno, este racimo conceptual demuestra la vigencia de un nuevo contexto crítico que debate de manera productiva con la tradición restringida a la "ciudad letrada" (Rama 1984) y su monopolio de la letra como instancia ordenadora de prácticas culturales y políticas. Ese contexto ha favorecido un retorno a ciertos paradigmas explicativos provenientes de la literatura comparada, depurados ahora del tradicional etnocentrismo de la disciplina. Si ya a principios de la década de 1990 los trabajos de Ana Pizarro (1994) auguraban que sólo un nuevo "comparatismo descolonizado", a la expectativa de constantes relaciones dialécticas, de "complejos procesos de resemantización", "asimilación creadora" o "antropofagia cultural", podía captar la heterogeneidad de la literatura latinoamericana moderna sin reducirla al "reflejo" de las metropolitanas, programas de investigación más recientes como el de María Teresa Gramuglio (2013) identifican en el problema de la traducción y los planteados por el análisis de las relaciones entre artes dos vías privilegiadas para releer el fin de siglo. Es en estas condiciones que el abordaje de los "salones" modernistas adquiere una singular relevancia. En particular, la recuperación de un corpus cronístico temprano de Rubén Darío, prácticamente inédito desde su publicación en 1895 -cuya existencia registrara Antonio Oliver Belmás (1968: 294), si bien la primera descripción y análisis corresponde a Malosetti Costa (2001 y 2004)-, puede contribuir al conocimiento de una práctica persistente no sólo en la escritura del nicaragüense sino también en la de las principales figuras del movimiento.

Si un rasgo destaca en los abundantes relatos críticos sobre el Ateneo de Buenos Aires - esa asociación de escritores, pintores y músicos fundada en 1892 a la que Darío se integra desde el día de su arribo a la capital porteña en agosto de 1893- es su carácter de alianza oscilante, de reunión de tendencias heterogéneas. La 
coexistencia de "jóvenes" y "viejos", nacionalistas y cosmopolitas, modernistas y naturalistas, descendientes de antiguas familias patricias y nuevos inmigrantes, pauta el tenor de ese "campo polémico" (Colombi 2004: 66) que recibe a Darío en un clima de efervescencia cultural sin precedentes para la ciudad. El difícil proyecto del Ateneo alentaba la fundación de un arte nacional efectivo en términos locales pero que, al mismo tiempo, participara sin menoscabos del fenómeno de mundialización cultural propio de las últimas décadas del siglo XIX. En efecto, como apunta Bibbó,

[e]ntre su fundación en 1892 y los años iniciales del siglo XX, esta asociación fue alternativamente, y a veces de manera simultánea, un lugar de definición y resguardo de la cultura nacional y un sitio propicio para la difusión de las novedades literarias europeas, además de un espacio de negociación entre posiciones estético-ideológicas disímiles y en algunos casos directamente contrarias. (2014: 221)

No obstante, para evaluar el alcance táctico-estratégico de las intervenciones darianas, es preciso detenerse en el carácter dialógico de ese espacio y remarcar el precario equilibrio de fuerzas que lo sostiene. En un contexto de revisión del proyecto modernizador de la llamada generación del ochenta, el Ateneo conjuga la tradición de un romanticismo nostálgico encarnado en la figura de Rafael Obligado -para quien la garantía del arte nacional se encuentra en el paisaje de la pampa visto por Esteban Echeverría- con el hispanismo de Calixto Oyuela -que junto a la reanudación de los vínculos culturales con España refuta todo intento de traducción o relación con las tendencias estéticas actuales y "foráneas" en tanto desafío a la supuesta pureza del idioma. Entre el nacionalismo criollo culto y el tradicionalismo hispanizante -tendencias esencialistas enfrentadas en un resonante debate público durante 1894- buscan su lugar los "nuevos", los "decadentes", los cosmopolitas que celebran el arribo de Darío a Buenos Aires, con el pintor Eduardo Schiaffino a la cabeza. Pero si este triángulo de fuerzas disyuntivas a propósito de los factores de un arte heterónomo o de las posibilidades de su autonomía relativa constituye el horizonte básico de inteligibilidad del salón dariano de 1895, otra querella transversal a las facciones en lucha resulta indispensable para comprenderlo. Se trata de la sutil controversia entre escritores y pintores -agudamente percibida en el desarrollo de Malosetti Costa (2001: 329-346)- por los "derechos" de la crítica literaria y de los jueces-literatos sobre la producción pictórica. En el seno mismo de los "nuevos" y contra el discurso diferenciador de Schiaffino - defensor acérrimo de una separación de las artes plásticas, que contaban, en su perspectiva, con un lenguaje, una técnica y una historia propias-, Darío vuelve a colocar a las imágenes y a sus productores bajo la tutela de las letras, gesto a partir del cual le confiere a la crítica una inusitada y decisiva función legitimante. 
Si bien es cierto que la formación artística de Darío avanzó siempre paralela a la literaria pues ya desde su temprana etapa chilena "la pintura había pasado a ser una fuente privilegiada de su inspiración culturalista" (García Morales 2004: 105), las crónicas del Salón del Ateneo responden a las condiciones específicas de escritura de las semblanzas que en 1896 integrarán el tomo Los raros, con las que convergen tanto en el ideario estético como en el nivel de sus operaciones retóricas. A caballo entre la crítica impresionista y los postulados del simbolismo -y en franca disidencia con criterios histórico-positivistas-, el salón dariano sostiene en su devenir una marcada desconfianza hacia la mímesis entendida no sólo como recurso de las obras mismas sino también como régimen de juicio en el discurso que las comenta. Es decir, junto al desdén hacia el color local, el matiz costumbrista, criollista o folklorizante -todas variantes de una inadmisible provincialización del arte-, los textos esquivan el parámetro de la verosimilitud como mecanismo para la asignación de valor a las imágenes. Una fórmula sorprendente, articulada en la sexta entrega de la serie, revela el criterio de juicio que reemplaza al circuito de la pulsión realista. Al glorificar una de las obras de la figura estrella del salón porteño, la crónica explica que su tela "es un Grasset que ha leído Rollinat y es amigo de Des Esseintes". En sintonía con los Salones (1845-1859) de Baudelaire, el del nicaragüense convoca a cada paso una moderna "biblioteca" que, mientras traduce y vuelve inteligibles las obras pictóricas a partir de las propias preferencias estéticas, le da entidad a una concepción de la cultura como cita de citas, sin referentes exteriores, extra-artísticos, a verificar o constatar. Esta misma concepción, deudora del fundador de la crítica moderna -si, como bien destaca Ana Lía Gabrieloni, "la crítica de Baudelaire «inventó» como poema el arte de Delacroix, transformando el hallazgo pictórico en búsqueda poética" (2006: 12)-, habilita el ingreso a los salones de una persistente entonación lírica que acerca la écfrasis dariana a las modulaciones del poema en prosa. En este sentido, la hegemonía abrumadora de la descripción en una sintaxis que prescinde de la narración y arma su secuencia paratácticamente -pasando casi sin transiciones del comentario de un cuadro a otro- constituye un indicio poderoso de la incidencia de las cualidades visuales y espaciales propias de las artes plásticas en los procedimientos de las artes verbales. Así, al tiempo que la écfrasis aspira a volverse ella misma "literatura" para competir con el objeto al que refiere, su retórica gobernada por el principio de la enárgeia, la capacidad de generar verbalmente la "visión" de lo que se describe- tiende a cancelar la dimensión temporal en favor de la analogía entre "lenguaje" y "espacio recorrido". Por otra parte, si Darío abandona ocasionalmente la écfrasis, lo hace para intervenir sin rodeos en las condiciones institucionales de la actividad artística. En este punto, quizá el bloque narrativo más importante de la serie sea el que construye una arqueología del arte moderno en Latinoamérica, diseño que inserta en las discusiones del Ateneo -encerradas en las posibilidades de una impronta nacional- una identidad inesperada, que reinterpreta la "argentinidad" en clave trans-americana. Junto a la crisis del criollismo y de la 
mímesis y la incorporación de una biblioteca rara como sistema de referencias para decodificar el arte "nuevo", el argumento de que el arte argentino (así como el chileno, o el uruguayo, o el colombiano, etcétera) adquiere visibilidad en una red mayor todavía por constituir -función que se autoasigna un movimiento atravesado por lo que Susana Zanetti (1994) entiende como su impulso "religador"- no hace otra cosa que socavar los presupuestos de las corrientes hegemónicas del Ateneo. A quienes esperan del arte el color local en que se reconoce la Patria Darío les ofrece, si no el rechazo contundente de la ilusión representativa, una trama identitaria alternativa, de nudos plurales dispersos en el continente. Frente a la pureza del origen invocada por criollistas e hispanizantes, las crónicas del salón articulan un nuevo diccionario crítico, que acriolla sin pudor los sistemas de valor de los centros modernos y configura un sujeto cosmopolita cuyo "deseo de mundo" (Siskind 2014: 3) sitúa sus intervenciones, al menos en términos imaginarios, en pie de igualdad con las culturas metropolitanas.

Pero la trama de referencias prestigiosas incorporadas al salón dariano brinda también la vía de acceso a una disputa menos evidente del lado de los compañeros de "campaña" en la cruzada modernista, controversia que señala los límites de la alianza entre pintores y poetas. Con razón James W. Heffernan ha insistido desde la teoría en el estatuto eminentemente retórico de la crítica artística, pues poco se ha hecho para demostrar "que sus juegos descriptivos son siempre interpretativos, que su objeto consiste en regular nuestra mirada, que tanto sus 'hechos' pictóricos como su estructura narrativa están diseñados por un intérprete que se erige en el embajador verbal del arte visual" (1999: 21; la traducción es nuestra). Eduardo Schiaffino, el mayor pintor aliado a la causa dariana por ese entonces, participa con vehemencia en el debate entre Oyuela y Obligado para poner al descubierto la asfixia que la pintura parece estar sufriendo a manos de los "intérpretes" letrados, siempre dispuestos a prescribir a las artes plásticas un repertorio convencional de bellezas "literarias", desde la llanura de Echeverría a los gauchos de Ascasubi. En la réplica que pronuncia en el Ateneo el 26 de julio de 1894, publicada en el diario $L a$ Nación tres días después y recogida en las páginas finales de su estudio La pintura y la escultura en Argentina (1783-1894), el artista plástico planta su descargo:

Como si el señor Obligado se propusiera no dejar subsistente la menor duda de que su confusión es absoluta respecto de los temas propios de la pintura y aquellos correspondientes a la literatura, cita versos de Ascasubi que tratan de la descripción de una laguna, y engañado por el resultado que el poeta obtiene, supone que el pintor podrá ir probablemente más lejos [...] [;] pero desgraciadamente los pintores no saben hacer lo mismo; lo invisible ya no les pertenece; si el poeta puede evocar a los antípodas con sólo hacer abstracción de la tierra, es presumible que los paisajistas tropezarían con ella. [...] En vano el señor Obligado nos presenta bellísimas descripciones del paisaje pampeano; en cuanto las analizamos del punto de vista pictórico acusan su esqueleto literario y se desvanecen a la manera de fantasmas de niebla barridos por el viento. No se 
podía, en verdad, elegir un ejemplo más cruel que aquel traído a colación por el poeta; el defensor de la estética de nuestra llanura, no ha encontrado más paisaje que ofrecernos que el miraje, una ficción brumosa. Cántela enhorabuena, en rimas perfumadas de aromas campesinos, y acompañe su acento apasionado en la guitarra llorosa del gaucho porteño, que tan bien ha pulsado Santos Vega. (1933: 358-359)

La sintonía de Schiaffino con los poetas "renovadores" del Ateneo y con Darío en particular, cultivada no sólo desde la convergencia en las predilecciones estéticas (Puvis de Chavannes, los grandes maestros del Simbolismo francés, Gustave Moreau y Odilon Redon) sino también a partir de proyectos conjuntos como la portada de Los raros que el pintor ilustra, es innegable y exhibe además la seducción de los artistas plásticos ante los circuitos de consagración letrada, más estables y con mejores garantías. Sin embargo, el rechazo de Schiaffino hacia el criollismo se acompaña de una defensa de la especificidad de los medios artísticos acosados por "fantasmas" de "esqueleto literario"- que Darío no podía compartir, al menos en su conjunto. Embarcado en una contienda con esos artistas a los que llama "súbditos de la realidad", el nicaragüense invoca el nombre, la palabra y las obras de uno de los campeones del esteticismo, James McNeill Whistler, en un gesto que parece coincidir con la búsqueda del pintor argentino, encaminada a liberar el arte de las presiones sociales más inmediatas. Pero, al mismo tiempo, todas las entregas del salón dariano vienen presididas por la insistente y emblemática voz de otro "maestro", John Ruskin, teórico clave de la Hermandad Prerrafaelita y feroz adversario de los planteos de Whistler. ¿Cómo explicar este solapamiento de autoridades, a primera vista incompatibles, reconciliadas por Darío en su desarrollo? ¿Se trata de una contradicción casual atribuible al misreading de quien se encuentra demasiado lejos del "centro" como para comprender los resonantes desacuerdos entre el artepurismo whistleriano y el pintoresquismo ruskiniano? A la luz de las múltiples protestas de la serie dirigidas a la mercantilización del arte en Buenos Aires, resulta plausible sostener que la cita del escritor inglés implicaba una toma de posición en "las polémicas que oponían el espiritualismo idealista al 'naturalismo de superficie' materialista y vinculado al positivismo cientificista", en contra de "aquellos que seguían la moda impresionista sólo por renovar sus formas y llamar la atención en los salones" (Malosetti Costa 2004: 112). Menos evidencias aportan las crónicas para concluir, con Malosetti Costa, que "al hacer suya la categórica definición del crítico inglés [...] el poeta se pronunciaba con total claridad (pero en inglés) contra la estética de l'art pour l'art"' (ibídem). Fuera de las contribuciones que ofrecen estudios como el de Kelly Comfort (2011) para contradecir esta aserción -al recomponer la trama de lazos transatlánticos entre el esteticismo europeo y el modernismo latinoamericano-, la contundente cita extraída de Modern painters (1843) admite una lectura como contraargumento frente a la propuesta de Schiaffino. No es preciso recorrer la 
galería completa de programas estéticos concebidos en Buenos Aires -basta con los prólogos a Los raros y Prosas profanas- para comprobar la persistencia de una defensa sistemática de la autonomía del arte; sin embargo, asumir la premisa ruskiniana de que el arte "es un noble y expresivo lenguaje" pero sólo válido en tanto "vehículo de pensamiento" implicaba recuperar para la crítica artística, para el propio discurso crítico-artístico, esa capacidad de pensar por las imágenes y hablar en su lugar que Schiaffino padecía y burlaba en su discurso del Ateneo. No es casual, en este sentido, que las dos pinturas más comentadas por el salón dariano Sinfonía en rojo y Lady Rowena, de Schiaffino- encuentren su valor en la analogía literaria proyectada una vez más sobre el lenguaje visual, pues ambas terminan recibiendo la tutela consagratoria de Edgar Allan Poe. Si Darío podía admitir y todavía alentar la lucha por la especificidad de los medios artísticos que afrontaba Schiaffino, la adopción de un "misticismo trascendente" en la línea de Ruskin trae a un primer plano las posibilidades de la écfrasis como estrategia creativa -hablar por las imágenes, expresar su "pensamiento", hacer literatura a partir de ellas-, prerrogativa exclusiva de los poetas a la que ni su prosa ni su poesía podían renunciar. De este modo, los salones darianos no sólo proveen un rico documento para captar las formas que adquiere la sociabilidad cultural en el fin de siglo, sino también una suerte de ventana hacia la "poética" desde la que se diseñan y calibran los alcances de los propios recursos literarios.

Presentamos a continuación las siete crónicas que componen el salón de Darío para el diario La Prensa. Hemos realizado mínimos cambios con respecto a los originales, corrigiendo -sobre todo- errores tipográficos que nos parecieron evidentes (abundantes en nombres propios y citas en lengua extranjera). Modernizamos la ortografía y la acentuación, pero conservamos rigurosamente la puntuación dariana. Consignamos nuestro agradecimiento a la Biblioteca "Dr. Raúl Prebisch" del Banco Central de la República Argentina, por brindar el acceso a sus fondos.

\section{EL SALÓN ${ }^{1}$}

En el Palacio de los Mercaderes, convertido por feliz imprevisión en asilo de las Artes, inauguran hoy oficialmente los pintores su tercer salón anual. ${ }^{2}$ Lo inauguran ventajosamente

${ }^{1}$ La Prensa, lunes 21 de octubre de 1895: p. 3, col. 7; p. 4, col. 1-2.

2 Organizado en el transcurso de 1892, el Ateneo de Buenos Aires -que preside inicialmente Carlos Guido y Spano, luego reemplazado por Calixto Oyuela al tiempo que Eduardo Schiaffino dirige la comisión de pintura- inaugura su local propio el 25 de abril de 1893 en la Avenida de Mayo n 291. Pocos días después de esta inauguración, el 15 de mayo, se monta allí una exposición de pintura y escultura que inicia la serie de Salones artísticos anuales del Ateneo, celebrados sin interrupción entre 1893 y 1896. El tercer Salón 
y la inauguración coincide con otras súbitas manifestaciones de anhelos intelectuales, en esta gran capital bursátil, tan mal mirada por los cultivadores de pensamiento, por los dueños de algún ideal, por los artistas sobre todo -escasos como en todas partes- que en ella padecen la celeste fiebre.

Mala fama tiene Buenos Aires entre los hombres de los cuadros, las estatuas, los versos y las partituras. Dicen que es una dama rica, estanciera, que ha viajado a París, que su casa está construida de buenos mármoles por mediocres albañiles; que su cochera es inmejorable; que gasta mucho en el modisto, pero que no posee ni un cuadro, ni un libro. ${ }^{3}$ Yo conozco a esos hombres y sé que son un tanto injustos. Visten hoy exactamente como los clubmen; pero son los mismos que antaño tenían largas cabelleras y grandes entusiasmos. Los peluqueros les han cortado los cabellos; mas siempre son los dueños del hermoso y santo fuego; siempre vuelan hasta la lejanía de sus deseos. Por eso ven tan gris en esta atmósfera metropolitana.

Sí, hay ambiente para el arte en Buenos Aires. Beruti no podrá decir que no, y el carcaj de Schiaffino ${ }^{4}$ debe estarse quieto ante alguna célebre kalofobia edilicia ya echada al olvido

del Ateneo abre sus puertas el domingo 20 de octubre de 1895, con un elegante vernissage y la exposición de unas 180 obras, de 71 artistas -dieciocho de los cuales son mujeres. El primer intento de relato historiográfico sobre este período aparece en la mirada de uno de sus más conspicuos protagonistas, Eduardo Schiaffino, con La pintura y la escultura en Argentina (1933). Para una descripción pormenorizada de las exposiciones del Ateneo entre 1893 y 1896 -y de sus repercusiones en la prensa de la época- ver Malosetti Costa (2001: 327-416).

3 Atinadamente apunta García Morales que el arte como "templo" y la ciudad como "factoría" "fueron metáforas reiteradas en los debates que en el Buenos Aires del último tercio del XIX plantearon las consecuencias del progreso y del crecimiento urbano. En la misma clase dirigente que abrió la Argentina a la modernidad y la inmigración pronto surgió la inquietud por sus derivaciones indeseadas, por la pérdida de su mundo de privilegios, que era sentida como una disminución de valores espirituales y nacionales" (2004: 111). Si bien estos discursos encontraron un punto de culminación en el Ariel (1900) de Rodó, habría que señalar la formulación temprana del calibanismo finisecular en el ensayo "Edgar Allan Poe" de Darío, publicado en la Revista Nacional (Buenos Aires) el 1 de enero de 1894 y luego incorporado a Los raros (1896). Este ideologema lo retomará la crónica unos párrafos más adelante.

${ }^{4}$ Eduardo Schiaffino (1858-1935), uno de los emblemáticos artistas viajeros de la belle époque, no sólo destacado por su talento pictórico sino también por el rol clave en la institucionalización del arte argentino, pues participa de la fundación de la Sociedad Estímulo de Bellas Artes en 1876 y en 1895 aparece como el principal impulsor de la creación del Museo Nacional de Bellas Artes, que dirigirá entre 1896 y 1910. Becado por el Gobierno para su periplo europeo en 1884, logró en 1889 que su cuadro "La toilette" fuera admitido en el Salón de París y que su desnudo "Reposo" ganara ese año la medalla de bronce en el certamen de la Exposición Universal. En París y hasta su regreso a Buenos Aires en 1891, tomó clases con Raphael Collin y Pierre Puvis de Chavannes, de quien se dijo "discípulo" y al que defendió de la crítica académica cuando aún no había sido consagrado como uno de los maestros del simbolismo. Malosetti Costa destaca la 
hoy que la estética municipal ha sido exaltada gracias a la disposición de un ministro plausible.

Entre los setecientos mil habitantes, más o menos, de este poderoso centro del continente, mientras las rotisseries y cafés nocturnos se pueblan de alegres gozadores de la vida, cuando los teatros se vacían, y en los salones se danza, o conversa de modas, de negocios, o de política, hay, no lo dudéis, lámparas que alumbran cabezas de soñadores, de trabajadores, que ponen la sangre de sus ideas a la ayuda de su sueño; hay muchos espíritus que se consagran a su obra, llevados de la mano y alentados por sus amigos inmortales, sus músicos, sus pintores, sus escultores, sus poetas. Sucede sí que estas fuerzas esparcidas no encuentran el instante de la atracción; sucede que esos elementos afines se mantienen separados por razones más o menos inexplicables, y que si llegase el día de su conjunción se podría saber a cuánto asciende y puede ascender la cultura argentina en lo relacionado con las Bellas Artes, y también, esto es claro, en el terreno del libro.

Se censura al público, al «burgués»; sería ya tiempo de defender al burgués. El público es el alumno de la prensa, y no puede sino seguir las corrientes señaladas por sus maestros, los que escriben para el público. ${ }^{5}$

El llamado burgués piensa con el diario que lee. Escritores, tesoneros que hagan la propaganda del Arte, son los que faltan. Hay que señalar los hermosos ejemplos; hay que aplaudir a quien se debe. No conocemos el stud del Dr. del Valle, pero sabemos que tiene la Diana de Falguière. ${ }^{6}$ Un caballo de raza es muy hermoso; pero habrá que conceder que es más hermoso un Degas, algo de Puvis de Chavannes, alguna violencia de Rodin. Hay que

excepcionalidad de Schiaffino como polemista, "una voz privilegiada en la medida en que fue uno de los principales protagonistas de ese momento auroral para la historia del arte argentino, no sólo como artista becado por el Gobierno, sino también, y sobre todo, como escritor y promotor de la causa de los artistas en la prensa" (2008: 24). Fuera de la alusión irónica al militar revolucionario Antonio Luis Beruti (1772-1841), la crónica parece referirse a la campaña pública emprendida por el pintor -que cuenta con artículos como "Estética de la capital (cuestiones ediles)", aparecido en La Nación el 19 de enero de 1894-, en la cual el artista sostenía con vehemencia que la falta de planes oficiales sobre las intervenciones urbanas conducía a una Buenos Aires "fea". Respecto del proyecto de reforma de la Plaza de Mayo, argumentaba contra el "desatino" de conservar la pirámide, "un deleznable pilar de ladrillos", que "tiene un aspecto tan banal que parece un accesorio de circo". Para la relación entre Darío y Schiaffino ver Malosetti Costa (2001: 378-416); completa y amplía este estudio el trabajo de García Morales (2004).

${ }^{5}$ Si bien -como apunta Malosetti Costa- las candentes discusiones en el Ateneo tuvieron como tema recurrente "el rol de los artistas y críticos en relación con la 'educación del gusto público"" (2004: 108), sorprende la lucidez de Darío que, siempre atento a las aristas del emergente proceso de institucionalización, señala en su "hacer crítico" el rol decisivo del periodismo como resorte para el arte nuevo.

${ }^{6}$ La estatua de Jean-Alexandre-Joseph Falguière (1831-1900) causó sensación en el Salon des Beaux-Arts de París en 1891. La segunda Diana que el consagrado Falguière enviaba a la exposición fue adquirida por el Dr. Sylla Monsegur, quien se la regaló a su amigo Aristóbulo del Valle (1845-1896), el político argentino fundador, junto a Leandro N. Alem, de la Unión Cívica Radical. 
persistir siempre en la protección del Estado para la educación estética, recordando el bello programa de cultura planteado por Schiller: es únicamente por el estado estético y no por el estado físico que el estado moral puede desarrollarse. Bien es que se prediquen a la continua las excelencias de la educación física; mas hay que dar aire a las alas de las almas, pues no es de desearse para este pueblo joven y grande, feliz conquistador del porvenir, una generación utilitaria, exclusivamente práctica, egoísta e indocta, que vuele hacia un ideal de gimnastas y danzantes en el Pegaso de la bicicleta.

Sobre todo, la obligación mayor es para con los que vienen, para con los que mañana han de ser los directores del espíritu nacional. Aquellos mismos yankees calibanescos, que tanto se curan del desenvolvimiento de sus energías físicas, a punto de renovar los juegos atléticos que celebrara Píndaro ${ }^{7}$, vuelven sus ojos a la divina Miranda. ¿Ser rico y fuerte es un motivo para desdeñar, para olvidar que no solamente somos carne y hueso? Miro, ciertamente, moverse la cabeza desaprobadora de los atacados de incurable bottomismo. ${ }^{8}$ Pocos son los caballeros de la luz, pocos los francos defensores, pocos los firmes amigos del triunfo de la idea.

Raros los que persisten en la tarea de misioneros del Arte, y muchos más los que imiten el ejemplo de esos excepcionales importadores de obras artísticas que educan el gusto, obras que son modelos provechosos y riquezas intelectuales.

El director del Museo de Bellas Artes ha clamado desde hace largo tiempo en pro del gusto nacional, ha hecho una meritoria campaña. ¿Hay muchos que hayan seguido sus huellas? ${ }^{9}$ Entre los esplendores comerciales y los progresos prácticos del municipio, en el tiempo áureo, las mal queridas Artes no tuvieron su parte de impulsión sino en censuradas construcciones y en otras sedicentes manifestaciones artísticas. Ah, si de otro modo se hubiese obrado, ya habrían encontrado los fundadores de hoy la base de un museo por compras y adquisiciones. Ahora, felizmente, adviértese como una especie de reacción y se ve como que se atraen y se animan unas a otras las energías existentes. Ese combatido

${ }^{7}$ Referencia a los primeros Juegos Olímpicos Modernos, en gestación por ese entonces y que tendrán su primera edición en abril de 1896.

${ }^{8}$ Anglicismo a partir de "bottomist": quienes, por propia voluntad y conscientemente, viven en actitud despreocupada -próxima al desprecio- del dinero y el consumo.

${ }^{9}$ Se refiere, obviamente, a Eduardo Schiaffino, designado como Director y Conservador del Museo Nacional de Bellas Artes por decreto del "plausible" ministro al que alude la crónica, Antonio Bermejo, el 15 de julio de 1895. El Museo abrirá sus puertas en diciembre de 1896, en el edificio del Bon Marché (más tarde Galerías Pacífico). Darío había colaborado explícitamente en esa "campaña" desde su llegada a Buenos Aires en agosto de 1893, en artículos como "El Hierro" para el periódico Tribuna (22 de septiembre de 1893): "La apoteosis del hierro puede decirse que ha sido proclamada en este siglo, en que se ha pretendido darle un alto puesto como material del arte. Huysmans atribuye al utilitarismo reinante el triunfo del hierro. [...] De Buenos Aires no se puede quejar. Acaba de inaugurarse una espléndida capilla de su culto en la calle de Piedad; capilla grandiosa, que honra al comercio de Buenos Aires, gracias a los señores Staud y Ca. ¿Cuál de nuestros bisnietos engendrará al arquitecto que señalará el mármol con que deba construirse el edificio del Ateneo, o de un lugar, llámese como se llame, consagrado al Arte y a las Letras?" (Darío 1938: 8-9). 
Ateneo es el causante de la animación. El Ateneo ha entrado en una nueva vía; en su amplio programa caben todos los esfuerzos, sin distinción de escuelas, sin preferencias ni prejuicios; quien tenga una idea que manifestar, una fe intelectual que predicar, tiene en el Ateneo medio y relativos elementos. A los hombres de letras y de ciencia, las conferencias; a los artistas, el Salón.

Amantes de las Artes, ayer habéis podido estar contentos. El pequeño Salón tuvo su pequeño público, en su día de vernissage. Las lindas mujeres visitaron a los pintores, en su fiesta de trabajo. Hoy todo está listo, los cuadros esperan. El público puede entrar.

\section{I}

Painting, or art generally, as such, with all its technicalities, difficulties, and particular ends, is nothing but a noble and expressive language, invaluable as the vehicle of thought, but by itself nothing.

Ruskin. $^{10}$

Dio el peninsular la primera noción del Arte al americano conquistado; el jesuita imaginero le enseñó a pintar y esculpir simulacros religiosos; de España vinieron para las gentes ricas, obras de grandes pintores.

Las casas de los nobles se enriquecían con firmas ilustres. Quito era un centro artístico, la Roma de la América colonial. La ingenua escuela quiteña no ha muerto todavía. México guarda antiguas adquisiciones notables.

En Lima hubo más de una pinacoteca particular digna de mención; entre ellas, la del señor José Dávila Condemarín, en la cual, si había muchas telas sin valor, se hallaban también obras maestras; y la galería de Ortiz de Zevallos, en el palacio de los marqueses de Torre Tagle, en donde existen, entre otros cuadros valiosos, un Dominiquino, La comunión de San Jerónimo, y un retrato del rey don Felipe IV y el Escorial, del gran Velázquez. Es

${ }^{10}$ La frase del teórico inspirador del movimiento prerrafaelita -que las seis entregas posteriores de la serie llevarán como acápite- pertenece al apartado "Definition of Greatness in Art" del primer volumen de Modern painters (1843). Damos una traducción: "La pintura, o el arte en general, como tal, con todos sus tecnicismos, dificultades y fines particulares, no es otra cosa que un lenguaje noble y expresivo, valioso como vehículo de pensamiento, pero en sí mismo nada". Desde la cita, el enunciador de la crónica busca erigirse en el lugar de un Ruskin para los artistas argentinos. Malosetti Costa lee esta contundente declaración de principios dariana - enunciada desde la distancia de otra lengua- como una toma de partido en "las polémicas que oponían el espiritualismo idealista al 'naturalismo de superficie' materialista y vinculado al cientificismo positivista. Esa fue [...] la clave del rechazo que desde comienzos de la década de 1880 los artistas argentinos expresaron por aquellos que seguían la moda impresionista sólo por renovar sus formas y llamar la atención en los salones" (2004: 112). En nuestro estudio introductorio ofrecemos una interpretación alternativa de este gesto dariano. 
esta galería de lo más digno de notarse que hay en el continente; además de siete salas de cuadros, poseía algunas valiosas esculturas, entre ellas un Cristo de Benvenuto. Explícase que no haya querido venderla su propietario, en dos millones de pesos oro.

En otras repúblicas americanas hay regadas, aquí, allá, viejas telas de precio. Sé de Riveras en Bolivia, un Martirio de San Bartolomé se encuentra en la catedral de Sucre ${ }^{11}-\mathrm{y}$ de otras obras semejantes, en el Perú, Chile, Ecuador, Colombia, y algunos lugares más.

Tuvieron, pues, buenos modelos que ver, sin ir a Europa, los pintores peruanos Laso de la Vega -el descendiente del Inca-, autor de una famosa Santa Rosa; Merino, de un no menos famoso Concierto religioso; Montero, cuya Muerte de Atahualpa se tiene como una de las mejores producciones de la pintura peruana; Torrico, fundador de la Escuela de Bellas Artes de Lima. ${ }^{12}$ No faltan los talentos y las disposiciones por aquellos países. Colombia se enorgullece con Urdaneta, a quien el arte en su país debe tanto; la América Central con Cisneros, cuyo retrato de la Emperatriz Eugenia obtuvo en París premio; Venezuela con Michelena, cuya ciudadanía parisiense es absoluta. En las Antillas, el nombre de Menocal basta para dar hoy cierto brillo a la pintura cubana. ${ }^{13}$ Pero en donde mayor cultivo ha tenido el arte pictórico desde hace algunos años, ha sido en Chile.

Ese país, tan rico en fuertes economistas, jurisconsultos y hombres positivos, como seco en imaginativos y poetas, el país del Código Civil y de los versos de don Andrés Bello, ha consagrado grande atención a las artes plásticas, a punto que, desde hace mucho tiempo, todos los años abre Santiago su Salón, en el cual, si la cantidad es más de notarse que la calidad, no deja de presentar firmas como las de Lira y, sobre todo, Alfredo Valenzuela otro ciudadano de París-, cuyas telas han inspirado a Armand Silvestre más de una encantadora página. ${ }^{14}$ El Uruguay tiene a Blanes. ${ }^{15} \mathrm{Y}$ bien, la República Argentina, que por

${ }^{11}$ José de Ribera y Cucó (1591-1652) -conocido también como "Lo Spagnoletto"- pintó en 1644 el óleo Martirio de San Bartolomé. En la catedral de Sucre se conserva una copia de esta obra -a la que posiblemente aluda la crónica- realizada por Elisa Rocha de Ballivián (1866-1956), artista oriunda de Cochabamba.

12 El catálogo peruano contempla las figuras de José Francisco Domingo Laso de la Vega y de los Ríos (1823-1869) -con su Santa Rosa de Lima, de 1866-, Ignacio Merino (1817-1876), Luis Montero (1826-1869) -autor de Los funerales de Atahualpa, de 1867- y Federico Torrico Mendiburu (1830-1879), todos pertenecientes a la generación de pintores republicanos de orientación académica.

13 La crónica selecciona cuatro personalidades de la pintura centroamericana, el colombiano Alberto Urdaneta (1845-1887), el salvadoreño Francisco Wenceslao Cisneros (1823-1878) -autor de varios retratos de Eugenia de Montijo, la esposa de Napoleón III-, el venezolano Francisco Arturo Michelena Castillo (1863-1898) y el cubano Armando Menocal (1863-1942).

14 Pedro Francisco Lira Rencoret (1845-1912) y Alfredo Valenzuela Puelma (18561909), ambos artistas chilenos. El segundo se consagró en el Salón de París de 1889, al recibir una mención de honor por su tela La Sirena (o la ninfa de las cerezas), obra que fue reseñada elogiosamente por Armand Silvestre en sus ejercicios ecfrásticos de la serie $\mathrm{Le} N u$ au Salon. Vol. 3 (Paris, E. Bernard, 1889).

${ }^{15}$ Juan Manuel Blanes (1830-1901), conocido por sus obras de asunto histórico-local rioplatense. 
sus elementos y vigores se ha colocado, por distintos aspectos, a la cabeza de las naciones americanas de lengua española, ipuede también lograr la hegemonía del arte! Ayer nomás se ha comenzado, y ya se recuerdan -a pesar de una indiferencia lamentable en tales asuntosrodeados de una hermosa aureola, los nombres de Fernández Villanueva, «el pintor de batallas», -y del deplorado Mendilaharzu. ${ }^{16}$ Habría que impulsar las enseñanzas del buen gusto, y acostumbrar al público a la frecuencia de esas enseñanzas. ¿Cuáles son nuestros Le Barc de Bouteville, nuestros Boussaud, nuestros Durand-Ruel? ${ }^{17}$ Unas cuantas vitrinas de comerciantes de bric-à-brac ${ }^{18}$, en donde los paseantes de la calle de Florida suelen mirar, rara vez, un cuadro meritorio, casi siempre abominables importaciones para la venta, paisajes de cartón, desnudos de caucho, crímenes de la paleta, innominables sacrilegios del dibujo. Hay publicaciones que por su condición especial deberían ser las guías e indicadores del gusto artístico general; pero dirigidas por criterios completamente estrechos, llevados tan sólo por la idea del lucro, ni enseñan nada, ni traen una idea nueva, ni hacen otra cosa que montar la guardia de la mediocridad, y adormecer al lector con el opio de sus banales doctrinas y con la influencia de su cerrado intelecto.

Dichosamente la labor de los pocos, aunque con lentitud, va triunfando. El Salón de este año supera con mucho a los dos anteriores. Es un esfuerzo que demuestra savia y vitalidad. Observemos de paso que en su producción -por número y calidad- los pintores se han colocado a una inmensa altura sobre los hombres de letras.

Al recorrer el Salón, hay, con todo, que lamentar algo, y es ello un triste desapego del ideal: señaladas excepciones - dos o tres- nos dan el sentimiento de una ascensión; la mayor parte camina buenamente sobre la tierra; la inspiración -o el oficio- encuentra su campo en eternos asuntos de todos los días; son temas banales, que hemos oído mil veces repetidos por todos los organillos de los talleres: quien decora con talento lo trivial; quien emplea un virtuosismo digno de mejor causa, en una escena caricatural y falta de nobleza. Poète, n'as tu pas des ailes? ${ }^{19}$

Recuérdese que los mismos artistas geniales, si pueden derramar la maravilla de los colores en la representación de cualquier objeto, lo hacen en un incontestable descenso de espíritu. ¡Dios mío! Cómo no envuelve en una adorable bruma el alma del contemplativo la milagrosa Gioconda de Leonardo; y cómo son de lamentar la pedrería de Rembrandt en el trozo de buey; los prestigios de Paul Potter en una cerda, la gracia de Chardin en una

16 Julio Fernández Villanueva (1858-1890) y Graciano Mendilaharzu (1857-1894) aparecen en los relatos fundacionales del Ateneo de Buenos Aires como los primeros mártires de la lucha por el arte nacional, casos paradigmáticos del artista desamparado que buscaba sin éxito el reconocimiento en la ciudad "fenicia".

${ }^{17}$ Célebres marchands franceses de la época.

${ }^{18}$ Del francés, "chucherías de bazar".

${ }^{19}$ Poeta, ¿acaso no tienes alas? La cita corresponde al poema "Ballade ailée" de Jean Richepin (en Mes paradis, 1894). Darío había usado la misma frase en "Jean Richepin. A propósito de su último libro: Mes paradis" (La Nación, 29 de abril de 1894), texto que luego pasa a la primera edición de Los raros (1896). 
brioche... ${ }^{20}$ No es exigir que entre nosotros se haga «pintura intelectual»; pueden estar tranquilos los que temen una invasión de decadentes; esos vértigos peligrosos no atacan sino cuando se ha llegado a ciertas alturas. Lo que sí sería la señal del sursum, es que en lugar de la persecución de tantos vulgares asuntos de la vida diaria, en lugar de invariables marinas y usadísimos géneros, se buscase un campo más elevado, mayor distinción; -que el alma personal anime la tela con la magia del estilo, que la composición se ennoblezca, que la síntesis se abarque con mirada superior.

RUBÉN DARÍO.

\section{El SALÓN}

$$
\mathrm{II}^{21}
$$

Painting, or art generally, as such, with all its technicalities, difficulties, and particular ends, is nothing but a noble and expressive language, invaluable as the vehicle of thought, but by itself nothing.

Ruskin.

Si en algo hay que asir el alma, si en algo tiene campo el artista -idifícil campo!- para hacer vibrar la psique, es en el retrato. Cuántos artistas y aficionados, dice Karl Robert, tienen la tentación de abordar el retrato desde que tienen la paleta en la mano, y no piensan en esta frase de un célebre pintor: Je n'ose aborder le portrait, tout cela me semble difficile $!^{22} \mathrm{Y}$ en efecto, ¿no os ha acontecido, ante un retrato de mérito, oír a unos afirmar el perfecto parecido, a otros negarlo por completo, tan cierto es que la verdad no podría ser la misma para todos? No es, pues, sino tras serios estudios que se debe abordar ese género y partir del principio, que es el espíritu y el estado habitual de la persona, hombre, mujer o niño, lo que se debe representar, más que la copia fiel de lo natural. Nada más cierto que esas palabras y no es nuevo el principio de que el parecido no es la primera cualidad de un retrato.

${ }^{20}$ La crónica se refiere a tres pinturas de asunto "banal": El buey desollado (1655), de Rembrandt; Dos cerdas en un chiquero (1649), de Paulus Potter; y La Brioche (1763), de Jean-Baptiste Siméon Chardin.

${ }^{21}$ La Prensa, martes 22 de octubre de 1895: p. 5, col. 2-4.

${ }^{22}$ No me atrevo a intentar el retrato, todo en él me resulta dificil. Desde fines de la década de 1870, Karl Robert (pseud. Georges Meusnier, 1848-?) dirigió la Bibliothèque D’Enseignement pratique des Beaux-Arts (Paris, Henri Laurens), colección bajo la cual él mismo publicó numerosos tratados "prácticos" como L'Aquarelle: figure, portrait, genre (1890), Traité pratique des peintures sur étoffes (1893), La peinture en imitation des tapisseries anciennes (1895) y Le vitrail simplifié: vitraux d'art, imitations diaphanes, leur emploi mis à la portée de tous (1895). 
Delante del Dr. del Valle por Schiaffino, ha desfilado una inmensa variedad de opiniones: que si el parecido es exacto, la factura es falta de animación; que el artista no debía haber colocado el modelo de perfil, pues no cuadra tal comprensión a los que siempre representan la figura abierta y amplia del orador; quien dice: «jallí no brilla la inteligencia!»; un crítico encuentra en el aspecto del conocido hombre público una apariencia de «prior de trapistas», o de «Schopenhauer, conculcador de todas las alegrías humanas». ${ }^{23}$

Es indudable: el Dr. del Valle de Schiaffino, lo que menos revela es un hermoso gesto de tribuno, pero es también cierto que el Dr. del Valle no vive en perpetua arenga: su alma tiene otras fases asibles, por ejemplo, su lado de artista, de pensador -su espíritu se podría transparentar del modo que vemos en este cuadro; y el perfil -manera cesárea y heroica, consagrada por las medallas y bajo-relieves- podía perfectamente aplicarse.

He tenido ocasión de oír de boca del autor la génesis de su trabajo. Para llegar a preferir el perfil, hubo antes de ensayar frente y tres cuartos; luego, su visión de portraituriste no quedó satisfecha y, después de estudios y vacilaciones, prefirió la última manera, la que se ve en el Salón.

No está, por cierto, a la altura de lo que se debe exigir del autor, este retrato; la exactitud de la semejanza corre parejas con la sequedad de la factura, y el estiramiento o rigidez que ha llamado la atención, ha sido probablemente efecto del momento de la pose.

Schiaffino conoce bien a su modelo, según tenemos entendido; le ha estudiado, le ha frecuentado, según el consejo de sir Joshua; ¿ha logrado dejar en el lienzo la expresión habitual $^{24}$

Sin embargo, ya se ha visto cómo ha meditado y procedido en conciencia, en la ejecución de su labor. Hay en él un pintor duplicado de un literato, y no puede dejar de saber

${ }^{23}$ Además de pintar su retrato, Schiaffino fue asesor en materia artística del político y coleccionista Aristóbulo del Valle (1845-1896). Meses después de publicadas estas crónicas, del Valle consiguió que el gobierno argentino comisionara a Auguste Rodin -por una suma abultada- el monumento conmemorativo de Domingo Faustino Sarmiento. La obra suscitó un escándalo en la Buenos Aires de 1900 y Schiaffino, defensor del "Sarmiento" de Rodin, mantuvo una intensa polémica con Paul Groussac, el más filoso detractor en 1896 de Los raros y Prosas profanas. Para la correspondencia entre del Valle y Schiaffino véase Malosetti Costa (2001: 236-237); el "escándalo Rodin" ha sido analizado en detalle por García Morales (2004: 144-151).

${ }^{24}$ Sir Joshua Reynolds (1723-1792), fundador y primer presidente de la Royal Academy, fue uno de los retratistas más influyentes en la pintura inglesa del siglo XVIII. En uno de sus Discursos (1769-1790) -el onceavo, de 1782- Reynolds argumenta que la mente del pintor, en familiaridad con su "sujeto", debe comparar las innumerables instancias de la forma humana para abstraer de ella las características típicas que representan su esencia ideal: "La excelencia del retrato y, debemos agregar, incluso la semejanza, el carácter y semblante, como he explicado en reiteradas ocasiones, dependen más del efecto general producido por el pintor que de la expresión exacta de las peculiaridades o la discriminación exacta de las partes. La atención del artista debe centrarse entonces en colocar los diferenciales en los lugares adecuados, lo que contribuye a dar el efecto y la impresión verdadera del todo". La traducción nos pertenece. 
que los retratos pintados se hacen lo mismo que los retratos escritos, según reza la indicación de Sainte-Beuve: se encierra uno durante quince días con un hombre célebre; se le estudia, se le mira por todos lados, se le interroga a voluntad, se le hace poser; es como si se pasasen quince días en el campo haciendo un retrato de Byron, de Scott, de Goethe; sólo que se está más a gusto con su modelo, y el tête-à-tête, al mismo tiempo que exige un poco más de atención, trae mucha más familiaridad. ${ }^{25}$

Cada rasgo se agrega a su vez y toma su lugar en la fisonomía que se trata de reproducir. Al tipo vago, abstracto, general, que haya abarcado la primera vista, se mezcla y se incorpora por grados una realidad individual, precisa, más y más acentuada y vivamente brillante; se siente nacer, se ve venir el parecido, y en el día, en el momento en que se ha tomado el tic familiar, la sonrisa reveladora, el pliegue indefinible, la arruga íntima y dolorosa, que se oculta en vano bajo los cabellos ya ralos, en ese momento el análisis desaparece en la creación; el retrato habla y vive: se ha hallado al hombre.

Y es probado.

Ha llamado con justicia la atención el cuadro de Della Valle ${ }^{26}$, Abuela y nieta. Todavía otro pintor que triunfa con el retrato de «Ma mère». Ha pintado Della Valle a su madre, sentada; tranquila y serena, tiene al lado, en el brazo del sillón en que descansa, una fresca niña, en el amanecer de su más bella vida.

Bastaría mirar esta obra para reconocer en quien la ha realizado un habilísimo ejecutante.

Si hay que calificar como defecto un exceso de minucias, tal sería el de este cuadro que nos ocupa; el detalle está estudiado con una atención sobrada, todo se ha observado de igual modo, los rostros como las puntadas de la costurera: Della Valle es uno de tantos fidelísimos súbditos de la realidad. La anciana señora vive, como la jovencita sonrosada; ambas han sido animadas por la notable técnica de ese artista, cuyas menores cualidades no son la franqueza y la finura de observación. De desearse sería, con todo, que lo descriptivo no excluyese lo emocional; querríamos, los que amamos algo más que la labor impecable de quien sabe su oficio, querríamos ver desprenderse de esa tela algo del alma misma del que la ha creado; y ya que se trata de un homenaje maternal, querríamos, por ejemplo, sentir algo semejante a la impresión honda que produce en el espíritu el cuadro en que el misterioso Whistler ha dejado los rasgos de su madre, aquella anciana sentada, de perfil, vestida de negro, que se destaca en un fondo oscuro y emblemático, tan sugestiva, tan vagamente triste,

25 Resulta curioso que Darío invoque los retratos literarios de Sainte-Beuve como referencia de prestigio, siendo que el "biografismo" del crítico francés se encuentra en las antípodas del proyecto llevado adelante en las semblanzas de Los raros.

${ }^{26}$ Ángel Della Valle (1855-1903) pintó en 1892 La vuelta del malón, una de las piezas clave para los artistas de la llamada "generación del 80", obra con la que obtuvo un premio en la Exposición Colombina de Chicago (1893). Esa pintura significó un hito en la conformación de un arte "nacional" ya que magnificaba la visibilidad del criollismo como asunto para la pintura al óleo de gran formato. Es evidente que Darío no comparte los presupuestos de esta orientación estética -devaluada en tanto "súbdita de la realidad"-, de modo que no sorprenderá la inmediata analogía con la obra de James Abbott McNeill Whistler (1834-1903), uno de los defensores más encarnizados de l'art pour l'art. 
concebida así en un feliz instante por el raro visionario que define el arte que venera y adora, con estas palabras: «C'est une divinité d'essence délicate, tout en retrait». ${ }^{27}$

$\mathrm{Si}$ queréis gustar de una deliciosa armonía de colores, colocaos ante el retrato de la señorita de Q... por Sívori. ${ }^{28}$ El rostro, lleno de juventud y gracia, está tratado con gran delicadeza. La figura en general, bien presentada, en una alegre visión de notas suaves.

Otro retrato, el de la señora de C., por el mismo pintor, obra de maestro; un rostro señoril, un aire de distinción bien rendu.

Y he ahí una cabecita, hecha á frottis, como que es un simple boceto; Sívori pintado por sí mismo. Está con su aire de artista, su cara de viejo-joven, y no solamente ha servido a la realidad en este «arranque», puesto que adivina en esos esbozos de su fisonomía, el espíritu suyo, la chispa intelectual que le anima.

No diré otro tanto del retrato del doctor Udaondo, que por muchos méritos que tenga, no deja de llevar también el sello de toda obra de commande. El distinguido caballero, actual Gobernador de la Provincia, se halla delante de su mesa de trabajo, entre libros, papeles y demás accesorios del gabinete de un personaje de su talla; estos accesorios, quizá recargados, están tratados sin firmeza, como correspondía, para no distraer la atención de la

${ }^{27}$ La crónica completa el contraste entre Della Valle y Whistler aludiendo a la pintura Arrangement in Grey and Black $N^{\circ} 1$ (1871) del estadounidense, obra cuyo título presenta un recurso insistente del esteticismo whistleriano: el paralelo entre color y sonido -en el "arreglo", vocabulario de la técnica musical- que viene a remarcar la autonomía del lenguaje pictórico al invocar su proximidad con el carácter no-referencial de la música. Vale recordar, en este sentido, la respuesta de Whistler en el proceso judicial que entabla con Ruskin a propósito del entredicho por su Nocturne in Black and Gold: The Falling Rocket (1875): “Al emplear la palabra 'nocturno' quise indicar un interés artístico autónomo, separando la pintura de cualquier interés anecdótico exterior, que de otro modo le habría sido sobreimpuesto. Un nocturno es un arreglo de línea, forma y color, antes que nada. La pintura es, de este modo, un problema que yo intento resolver" (Whistler en Dorment \& MacDonald 1994: 122; la traducción nos pertenece). La cita de cierre del párrafo corresponde a la conferencia Ten O'Clock ofrecida en inglés por Whistler -en Londres, Cambridge y Oxford, durante los primeros meses de 1885. Darío la toma de la traducción al francés que en 1888 publica Stéphane Mallarmé bajo el título Le "Ten O'Clock" de M. Whistler (Paris, Librairie de la Revue Indépendante), aunque la misma frase figura también en Certains (1889), el tomo de semblanzas de Huysmans que el nicaragüense comenta en sus "Mensajes de la tarde" (1893-1894): "[El arte] es una divinidad de delicada esencia, siempre en segundo plano". Pocos meses antes de publicar estas cónicas del Salón del Ateneo, en el artículo "Fiestas primaverales. Los poetas y las flores" (La Nación, 14 de noviembre de 1894), Darío daba a conocer la primera traducción de Mallarmé al español, una versión del poema "Les fleurs" (Les poésies, 1887). Para el vínculo con Mallarmé ver el notable desarrollo de García Morales (2006); un análisis del "uso" propiamente dariano de la conexión entre pintura, música y poesía puede leerse en Caresani (2014).

28 Eduardo Sívori (1847-1918), uno de los principales fundadores, en 1876, de la Sociedad Estímulo de Bellas Artes, institución que comenzó a reunirse en una barraca de su padre. Esa asociación marca el inicio de un proceso que culminará con la inauguración del Museo Nacional de Bellas Artes en 1896. 
figura principal: la persona retratada, un brazo apoyado en la mesa, y el aire general como en el curso de una conversación.

El arte embellece todas las bregas de la vida: así, sobre la mesa del político, canta, en su tono de colores fugitivos, suavemente, un ramo de flores. No dejaremos de decir que esta clase de retratos, más que parecerse a los retratos llenos de accesorios, del siglo XVIII, tienden mucho al fotografismo, de tal guisa que el Doctor Udaondo de Sívori podría iniciar la galería argentina de Nos contemporains chez soi. ${ }^{29}$

Y aquí está Roberto Payró, pastel de la Cárcova ${ }^{30}$; Roberto Payró bien traducido: pues a través de ese rostro, de esos ojos inteligentes, y de esa juventud briosa, ha podido mirar el artista el dejo de fatiga que hay en todo trabajador del cerebro y, sobre todo, en quien ama como Payró esas mismas fatigas matadoras.

Un discípulo de la Cárcova, Ripamonte ${ }^{31}$, presenta un maestro Pini, en que demuestra envidiables cualidades. Hay en él muy buena visión del color, como influido por su maestro -mas esa influencia de Cárcova no le impide que él también vaya viendo por su lado. La actitud está directamente estudiada. Es de lamentar, no obstante las buenas condiciones, que no haya creído deber apagar las clarinadas rojas del fondo. Con un fondo menos «sonante» hubiera ganado mucho la tela.

No dejaré de nombrar el escultor Cantillón, de Schiaffino, un excelente estudio en que ha vencido ciertas dificultades -sobre el fondo lleno de luz, y la cabeza más oscura- que no se creerían muy apropiadas para el retrato.

Uno enorme, de Bouchet: el del Coloso de Rodas o el Milón de Cretona, Gog, Magog, Sansón o Fierabrás, de cualquier gigante en fin. Buen pintor, iy de tan mal gusto! Su obra es una cabeza monumental, de hombre joven, hecha con conocimiento del arte, pero de tal modo, que da al espectador la idea de un Gulliver que contemplase una pintura de Brobdignac. El efecto no es de ninguna manera agradable.

${ }^{29}$ Referencia a la serie Nos Contemporains chez eux (nuestros contemporáneos en su casa) con la que el fotógrafo francés Dornac (pseud. Paul François Arnold Cardon, 18581941) inaugurara en la década de 1890 la circulación masiva de fotos de "celebridades".

30 Ernesto de la Cárcova (1866-1927) había presentado en 1894 -para la segunda Exposición del Ateneo- Sin pan y sin trabajo, obra que lo ubicará entre las figuras centrales del arte nacional. Hacia julio de 1894, de la Cárcova se incorporaba -junto a Schiaffino y Roberto J. Payró (1867-1928)- al Centro Socialista Obrero. A propósito de este cuadro, Payró escribió una encendida reseña en la que destacaba el vínculo con la actualidad política: “' ¡Sin pan y sin trabajo!’ Por la ventana, que deja entrar la luz gris, semi-azulada de una tarde invernal, se ve confusamente el grupo de los obreros en huelga, que en un momento de desesperación se han rebelado y ni quieren seguir dando pedazos de su vida a cambio de un mendrugo insuficiente. [...] ¡Oh! ¡miserables! ¡Allá están! Allá gritan y peroran, y se enfurecen, como si hubiera remedio para esto, como si el hambre se acallara con discursos" (La Nación, 3 de noviembre de 1894).

${ }^{31}$ Carlos Pablo Ripamonte (1874-1968), joven de 20 años para este momento, será una figura de transición, principal impulsor del grupo Nexus que se fundaría en 1907. 
El Sr. Piñero, por Pagano. ${ }^{32}$ Parece imposible que este autor que presenta un muy recomendable retrato suyo, sea el mismo que ha pintado aquella tela; tan opuesta es una producción a otra.

Artistas que estáis tentados por la figura humana, recordad que es la más misteriosa, la más complicada, pues en ella, en la faz del hombre, a flor de piel y bajo el cristal de los ojos, tenéis que encontrar esas luces que se llaman las ideas, y esos estremecimientos que se llaman las pasiones. En el rostro de la mujer tendréis siempre un esfíngico enigma que debe comprender vuestra paleta; en toda representación del ser humano, un estado de alma que penetrar. Recordad también que vuestro pensamiento debe imprimir su carácter singular a las telas que animéis; recordad a los grandes maestros inmortales que dieron alas a la personalidad; recordad que, como afirma Charles Blanc, «si las obras del arte deben ser medidas según la cantidad de espíritu que esas obras exigen, la perfección del retrato es la última palabra de la pintura ${ }^{33}$; recordad cómo Ticiano ponía en sus retratos su majestad, Turner su magia, Antonio Moro su distinción, Rembrandt su luz propia, y Vinci su propia alma que envuelve como un velo amoroso la faz de la Monna Lisa.

Que os vean en vuestras obras, los que las contemplen; que vuestro ser compenetre con la luz, y uno y otra se revelen sus secretos.

El arte es un «lenguaje expresivo y noble» que os servirá para manifestar vuestra comprensión de la naturaleza y la más dificultosa del misterio humano.

Y ascended: que no os aten los pulpos de la vida común, en una realidad que os haga no mirar al cielo: que de arriba os viene la luz.

RUBÉN DARÍO.

\author{
EL SALÓN \\ $\mathrm{III}^{34}$
}

Painting, or art generally, as such, with all its technicalities, difficulties, and particular ends, is nothing but a noble and expressive language, invaluable as the vehicle of thought, but by itself nothing.

Ruskin.

32 José León Pagano (1875-1964), pintor dedicado a la literatura y la crítica de arte, publicó entre 1937 y 1940 una monumental obra histórica en tres tomos, El arte de los argentinos. Allí se refiere elogiosamente al pintor español José Bouchet (1848-1918), "un olvidado" según su perspectiva (1937: 317). La obra de Pagano como pintor y dibujante es, aún hoy, poco conocida.

${ }^{33}$ La cita traducida de Blanc pertenece a su tratado Grammaire des arts $d u$ dessin: architecture, sculpture, peinture (Paris, Henri Laurens, 1867).

${ }^{34}$ La Prensa, miércoles 23 de octubre de 1895: p. 5, col. 1-3. 
Cuenta Teodoro de Banville que en una ocasión vio a su amigo Corot luchar por el tiempo de seis semanas, batallar, encarnizarse en una pequeña parte de arroyuelo tranquilo en el fondo de un bosque, alumbrado por los vagos reflejos del sol poniente, el cual arroyuelo no ocupaba en la tela casi el lugar que ocuparía una moneda de cuarenta sueldos. Esa pequeña parte habíala el artista borrado y raspado veinte veces y, cada vez que la rehacía, sus amigos la encontraban obra maestra; pero él sacudía su buena cabeza espiritual y burlona, bajo el gorro de algodón rayado de rosa. Eran en verdad obras maestras las que producía en la sucesión de sus tentativas; pero no «lo que él quería», la impresión trémula, vibrante, que tenía dentro de sí.

Y cuenta Max Sulzberger que un día, después de varias horas de exquisita contemplación de las obras de ese mismo maravilloso pintor en el hotel Gallera, dando una vuelta por el Bosque en compañía de un amigo, a cada rato, ya a la entrada de la Alameda de las Acacias, todas en flor, ya al volver por el camino que presentaba bruscamente a sus miradas el espejo del lago, bajo los ramajes de un verde primaveral, se sorprendían mutuamente con esta exclamación: «¡todavía un Corot!». Esos recuerdos dan idea de cómo llegó a entender el ilustre maestro el secreto de la naturaleza, y cómo estimaba el valor íntimo de la impresión personal.

No hay que buscar en los paisajes expuestos en el Salón del Ateneo ni la más remota semejanza con la altísima memoria; en casi todos se advierte el métier; en los mejores, el don que se resume en una buena vista y una mano ligera.

Las palabras que brotan de los labios delante de algunos de esos cuadros son estas: «muy bien hecho». Pero nada más. Es que, a la primera tentativa, los amigos de taller han encontrado la obra «maestra» y ellos, los pintores, lo han creído, sin mover la cabeza como Corot. ¿Es que no hallan la expresión del Pensamiento, o que no tienen Pensamiento que expresar?

Tal puede juzgarse al mirar los paisajes de Paolillo ${ }^{35}$, por ejemplo, presentados en este Salón y, entre ellos, delante de un estudio que puede señalarse como un modelo de factura hábil: en primer término, la entrada de una quinta, o casa de campo; una enramada, una rústica glorieta; en el fondo, alumbrado de sol, el boscaje, puntuado de flores rojas. Todo está hecho con prolijidad tal que diríase que el pintor sabe el número de hojas de la enramada; apenas, en el fondo, la vegetación está tratada a grandes masas; el color es una de las buenas cualidades de la obra. Mas esas cosas pintadas allí son cosas sin alma; no despiertan en nuestro ser emoción alguna; es la traslación al lienzo de una naturaleza sin voz y sin lenguaje.

Ballerini ${ }^{36}$ nos ha dado en un cuadro de bien ideada composición, Origen milagroso de Nuestra Señora de Luján, un paisaje en que al mismo tiempo que una exactitud real del

35 Luigi Paolillo (1864-1934), paisajista italiano; incansable viajero, vivió en Buenos Aires entre 1890 y 1903 y, más tarde, entre 1907 y 1913.

${ }^{36}$ Augusto Ballerini (1857-1902) fue uno de los pintores más activos del Ateneo y la Sociedad Estímulo de Bellas Artes, aunque también participó -junto a de la Cárcova y Della Valle- del grupo disidente llamado La Colmena Artística. Su obra Una noche de luna en Venecia, expuesta en el Salón y a la que la crónica se refiere más adelante, constituyó la 
medio manifiesta, entre opacidades de amanecer, en una escena en pleno aire, un soplo de religiosidad campestre que pasa sobre esos habitadores de la Pampa de 1630, como ha pasado sobre los crepusculares campesinos de Millet.

De notar es, en ese lienzo tradicional que ha impresionado bien a la crítica y a los visitantes, que la indumentaria de los tipos en él creados se resiente de extremada modernidad, de tal manera que hoy mismo no causarían extrañeza.

Ballerini ha ido al «dulce Lambaré»" ${ }^{37}$ a encontrar el tema de otras dos telas suyas: Embarque de naranjas en Villeta y Paraguay. En ambas revela concienzudos conocimientos de perspectiva y de composición.

Sus indias paraguayas, esas mujeres morenas, fumadoras, ya adornadas las cabezas con pañuelos de colores vivos, ya envueltas en sus largos mantos blancos, caminando cargadas de cestos de naranjas, canéforas salvajes, o sentadas en cuclillas ante sus canastas de frutos, en esos paisajes de luces accidentales, cerca de las aguas quietas, o en los caminos, traen a la memoria en cuanto al tema la obra rara de Gauguin, el artista extraño que ha ido a buscar asuntos para su paleta a la tierra de la reina Pomaré.

Ha salido Ballerini fuera de las trilladas sendas, y váyale por ello el aplauso de los que proclaman la guerra a todo lo usado y trivial. Ha buscado esta vez sus modelos en esa curiosa raza del país paraguayo, raza envuelta en una bruma de tradición trágica, con carácter propio, exótica entre estos centros invadidos por la civilización europea, y en la cual el artista puede encontrar un copioso número de revelaciones y de apariencias -con la sola condición de saberlas comprender.

¡Diminuto Saint-Clair-Sur-Epte! ¡Casitas de Gisors! ¿Vosotras visteis pasar al pintor argentino, quizá en alegre y sonrosada compañía, cuando iba a plantar su caballete para copiar ese rincón del Epte en que el agua tranquila refleja en su fondo oscuro los árboles, las grandes manchas de verdura? Ese aire que allí discurre, esa luz clara del fondo, esos boscajes umbríos, cuántos recuerdos despiertan en los que han pasado a solas con su sueño o con su alegría o con su nostalgia por las márgenes de las corrientes que dan su tributo al gran río a quien el poeta impreca:

-Et tu coules toujours, Seine, et, tout en rampant, Tu traînes dans Paris ton cours de vieux serpent, De vieux serpent boueux, emportant vers tes havres Tes cargaisons de bois, de houille et de cadavres! $!^{38}$

primera adquisición de un cuadro de artista nacional realizada por el Estado argentino para el Museo Nacional de Bellas Artes.

37 Alusión al poema "Nenia" de Carlos Guido y Spano, recordatorio del genocidio ocurrido en la Guerra de la Triple Alianza: "En idioma guaraní, / una joven paraguaya / tiernas endechas ensaya, / cantando en el arpa así, / en idioma guaraní: // ¡Llora, llora urutaú, / en las ramas del yatay, ya no existe el Paraguay / donde nací como tú- / llora, llora urutaú! // ¡En el dulce Lambaré / feliz era en mi cabaña; / vino la guerra y su saña / no ha dejado nada en pie / en el dulce Lambaré!" (Hojas al viento, 1871).

${ }^{38}$ Se trata de la estrofa final del "Nocturne parisien" de Paul Verlaine, texto que integra la colección Poèmes saturniens (1866). Reproducimos la traducción del poeta español Emilio Carrere: "Y tú, Sena impasible, deslizas tu corriente, /que cruza por París igual que 
No hay que olvidar dos sonatas venecianas, de Ballerini. En la una, Venecia de noche, feliz efecto del clair de lune; una melodía apacible, turbada solamente por la visión de una Venecia profanada, en que sustituye a la góndola el vaporcito... En la otra, Venecia de día a gondolare-, una armonía de tonos claros y vibrantes: una mujer, en blanco, que se destaca sobre los edificios llenos de sol, de pie en el embarcadero, se prepara a descender a una góndola, en donde le aguarda una compañera.

Escardó $^{39}$, pintor español, presenta un paisaje de grandes dimensiones: El río Santa Lucía después de una creciente. A primera vista, se revela el autor un estudioso: observa con exactitud y sabe sacar provecho de las luces y sombras; mas podríasele censurar una extremada liberalidad de color.

Así al Sr. Bonifanti ${ }^{40}$, que expone su Tristia; en el cual lienzo os llama a pesar vuestro la mirada, antes que todo, un trozo de cielo azul, de un tono furioso, sobre el cual se extiende un enorme nubarrón ahumado. El paisaje en general es triste. En la ejecución el autor revela poco estudio de los valores y ha empleado con algún abuso la pleine-patte, en ciertas partes que se asemejan a verdaderos trozos de mapas en relieve.

$\mathrm{Mayol}^{41}$ ofrece un paisaje en que hay aire y luz, sobresaliendo una fila de árboles estudiados con excelente visión. Y Pagano un Crepúsculo que, como mayor particularidad, presenta en su fondo algo como una erupción volcánica en una montaña rusa...

Marinas dignas de mención encontrará el visitante muy pocas: una grande machine de Auzón $^{42}$, Recuerdo del Atlántico -un barco bajo la tempestad, desfile de todos los verdes

una serpiente / monstruosa, caminando hacia lejanos puertos / con tu carga de hulla, de madera y de muertos" (Románticas y otros poemas, 1921).

${ }^{39}$ Héctor Escardó (1866-1896) llega a Buenos Aires en 1890 y alterna su estancia en la capital con ocasionales viajes a Montevideo, donde mantiene una fluida relación con el paisajista uruguayo Manuel Larravide (1871-1910), también mencionado en la crónica.

${ }^{40}$ Decoroso Bonifanti (1860-1941), pintor y escenógrafo, integra el nutrido contingente de artistas italianos en la capital argentina.

${ }^{41}$ Manuel Mayol Rubio (1865-1929), dibujante y pintor español radicado a partir de 1888 en Buenos Aires. Desde su arribo a la ciudad colabora con el semanario satírico Don Quijote y luego participa en la fundación de Caras y Caretas (1898). En 1895 forma parte del exiguo grupo de artistas españoles que expone en el Salón, presencia notable ya que los "españoles" -nucleados en el grupo opositor al Ateneo, La Colmena Artística- se habían mantenido al margen de ese circuito desde de la polémica entre Rafael Obligado, Calixto Oyuela y Eduardo Schiaffino (1894) por las posibilidades de una impronta "nacional" en el arte y la literatura. Malosetti Costa señala a Mayol como el autor de "las notables caricaturas anónimas que la revista Buenos Aires [año I, n. 30, 27.X.1895] publicó [...] burlándose de muchas de las obras expuestas, en particular de las de Schiaffino y los 'decadentes' como Diana Cid García” (2001: 377). Esas imágenes de Mayol -junto a otras manifestaciones que consigna la investigadora argentina- pueden leerse como respuesta indirecta a las intervenciones de Darío en el Ateneo y a sus juicios para La Prensa.

${ }^{42}$ El término "grande machine" es vocabulario específico de la crítica artística y designa a aquellas pomposas pinturas históricas que, en la tradición del academicismo, apelan con recursos trillados al "pathos" del público. Max Eugenio Auzón -pintor, crítico de arte y 
marinos-; y dos de Larravide: en la una dos vapores, que a primera ojeada parecen uno solo, entran a la rada; se miran a una regular distancia y, sin embargo, podríais conocer a los pasajeros que fuesen en ellos si os fijaseis; el cielo da la sensación de un cielo vertical; el agua del río está bien coloreada, y siéntese sobre ella el viento; una barca pescadora, con su gran vela latina, contribuye al esfuerzo pintoresco; la otra tela de menores dimensiones, Ushuaia, revela el mismo procedimiento; el autor se ha enamorado del agua, sin saber que es «pérfida» como la mujer; pero sobre sus creaciones no hallaréis un solo rayo de Arte; es un buen «pintor»; su obra en los Estados Unidos sería aplaudida por todos los innumerables pintores que no se llaman Whistler.

Se ha señalado en estas notas la particularidad de que no tenga casi representantes el ideal en este Salón. Agréguese que señalados han sido los sacerdotes del culto de la tentadora carne femenina. Le Nu au Salon se reduce a la Zelika de Parisi, a la Sinfonía en rojo de Schiaffino, a dos hemisferios de goma elástica de Sábat, y una escultura, la Bacante, ya célebre entre nosotros, de Dresco. ${ }^{43}$

A un joven poeta que me acompañaba en una visita al Salón, he pronunciado la siguiente arenga delante de cada uno de esos desnudos: «Ama, oh joven -le he dicho- a esa mujer que el artista ha desvestido en ese fondo sangriento, en ese fondo purpúreo, en ese fondo en que vibra toda la gama de los rojos; no la desdeñes por el dibujo de las piernas, por la $\mathrm{S}$ dura que desciende desde la cadera, por el brazo inarmónico que levanta la opulencia mamaria; el rostro debe de ser bello: su sangre es joven y viva; y el velo de una pasajera vergüenza, o de una pena repentina, o de un pudor retardado, oculta en ese instante la sabiduría perversa de sus caricias; y ámala, sobre todo, porque puede darle nuevo ser quien se atreve y vence poniendo un alma a las mujeres de Poe.

De Zelika desconfía, porque es una inanimada, Zelica de Batignolles: sus joyas son joyas de bazar; sus ropajes son espejo de ropajes naturales; pero toda la habilidad de su creador no será bastante a infundirle un soplo de vida, a darle una gota de sangre: esa sonrisa no promete nada, y ese vientre, esos senos redondos y firmes, esos ojos de cristal, son los de una polícroma estatua de cera.

A la Bacante de Dresco dile versos en griego que te enseñará mi amigo Holmberg, porque es en verdad de la familia de las antiguas Ménades; en su rostro está la beodez

funcionario estatal, español de nacimiento- mantuvo con Schiaffino una violenta polémica que concluyó en un duelo a espada a fines de 1891.

${ }^{43}$ Enfrentado a los desnudos del italiano Franco Paolo Parisi (1857-1948), del español Hermenegildo Sábat Lleó (1874-1932) o del argentino Arturo Dresco (1875-1961), el cronista se detendrá otra vez en el trabajo de Schiaffino, significativo por la sinestesia del encabezado -Desnudo. Sinfonía en rojo- pues el gesto dialoga con el procedimiento de las célebres sinfonías whistlerianas que cifraban en el título sinestésico la búsqueda de una pintura desligada de la referencialidad, "autónoma" como la música. El artilugio podría venir sugerido también por una tradición local encarnada en el poema "Sinfonía en gris mayor" del propio Darío, ejercicio ecfrástico que el nicaragüense compone en Guatemala (1891) pero vuelve a publicar en Buenos Aires pocos meses antes del Salón (en el periódico Tribuna, el 8 de enero de 1894). 
alegre, en sus pechos el llamamiento a las fiestas de Afrodita, después de las fiestas de Baco; su cuerpo todo está lleno de turbación; es la Mujer; como ella, tiene defectos; pero me ha dicho al oído que cuando Dresco haya ido a París y estudiado más, y visto al inmenso Rodin, va a tener ella otras hermanas, mucho más hermosas, mucho más vivas, mucho más valiosas...»

Y como yo quisiese continuar en mi peroración, me dijo en silencio un robusto señor que criticó detrás de mí con una gran voz:

$-«$ ¡Ese tobillo es demasiado gordo!»

RUBÉN DARÍO.

\section{EL SALÓN}

$\mathrm{IV}^{44}$

Painting, or art generally, as such, with all its technicalities, difficulties, and particular ends, is nothing but a noble and expressive language, invaluable as the vehicle of thought, but by itself nothing.

Ruskin.

La pintura de género tiene en la señora de Witt una distinguida cultivadora. ${ }^{45}$ Fijaos en su cuadro, Luto, que augura en quien lo ha hecho una serie de obras plausibles. Una mujer, una madre, sentada, apoyada en una mesa, está triste, llena de dolorosa angustia; cerca de ella, el marido, con la cabeza inclinada, muestra asimismo en la faz y en la actitud un sendo dolor. No hay duda que $E ́ l$ ha muerto: bien comprendéis desde el primer instante que él es el niño amado, el hijo que alegraba el hogar. La madre apoya su cabeza en una mano; la otra la tiene sobre la mesa. Y parece decir: «Mirad mi duelo y mi melancolía; pero mirad también qué bien dibujada está mi mano izquierda. Dibujar una mano: ¡ahí es nada! ¡El soneto de los pintores!»

$\mathrm{Y}$ en efecto, esa mano izquierda es de un perfecto dibujo, que contrasta con el dibujo del cuadro en general, un tanto descuidado. En la composición hay delicadeza y unidad: nada es superfluo. La emoción se produce, por el justo equilibrio.

Otra dama, la señorita María Huergo, discípula de Sívori, ha presentado una tela que he de mencionar con gusto: Une cigale. No creáis que es una obra bien hecha: la señorita Huergo es un talento que todavía no sabe pintar. «La pintura es un arte de mujer», dice

${ }^{44}$ La Prensa, viernes 25 de octubre de 1895: p. 5, col. 2-3.

${ }^{45}$ Hacen su entrada a la serie las artistas femeninas, en las figuras de Graham Allardice de Witt (1855-1947) y María Huergo (1871-1921). La mención le otorga cierto protagonismo a la mujer, un actor minorizado, casi anónimo en el arte del fin de siglo, si bien se trata en ambos casos de pintoras que "auguran" obras por venir pero que, al presente, producen cuadros de factura defectuosa y limitados a asuntos triviales -ni la pintura histórica ni el retrato del prócer sino la vida doméstica o el folklore. 
Miguel Ángel: y este es uno de los casos en que se estaría dispuesto a creer en la boutade de Buonaroti, tal es la delicadeza femenina con que ha concebido su creación la artista. Une cigale. No se trata de la divina cantatriz de los bosques de Grecia, que vivía de rocío, tan amada de los poetas; se trata de aquella que cantando «pasó el verano entero, sin hacer provisiones»; de aquella pobre cigarra de Lafontaine, que cantaba, cantaba y cantaba; de la cabecita a pájaros, de la poetisa, a quien, cuando tuvo frío en el invierno, le negó la entrada en su casa su amiga la hormiga, esa burguesa.

María Huergo ha dado a su cigarrita una cara adorable, un cuerpo de niña que llega a la adolescencia.

Nótanse en la ejecución ciertos defectos de dibujo - por ejemplo un brazo que aparece recortado por la manga, o como un brazo de maniquí-, pero todo eso es perdonable. La señorita Huergo ha puesto «poesía» en su figura, ha comprendido su asunto con su fino talento, y ello augura mucho de primer orden para más tarde.

El primer mate, por A. Caraffa ${ }^{46}$ : un inglés que visita una casa de buen tono en el Buenos Aires de hace unos cuarenta años se ha quemado con el mate que se le ha ofrecido, y da muestras de ello, con sus gestos, con su actitud, con su cara colorada como una langosta. La cosa tiene mucha gracia, como se ve por los rostros de las gentes de la casa, desde la abuelita hasta la negrilla que ha servido la tisana.

El salón está pintado con gran minuciosidad, los menores detalles han sido consultados. Quién sabe hasta qué punto peligre el buen gusto del autor -en esta obra censurada por unos, celebrada por otros.

Es un tema bien compuesto y tratado con harta habilidad y estudio; tiene rasgos de mano maestra; caras hay excelentemente manifestadas; la escena es viva; pero ;querer hacer obra de artista con semejante asunto! Quien dice que esa escena no corresponde a la sociedad porteña de aquella época, cuya cultura, cuyas maneras, eran por tradición finas y correctas; quien que esos vestidos parecen sacados de un viejo ropero de Provincia. Oh, señor Calzadilla $^{47}$, en verdad ¿vestían tan feamente esas beldades?

${ }^{46}$ Emilio A[ngelini]. Caraffa (1862-1939), virtuoso acuarelista argentino ya consagrado para este momento. A propósito de las obras argentinas enviadas a la Exposición de Chicago, A. Atienza y Medrano comentaba el 1 de enero de 1893: "El pintor argentino Sr. Caraffa presenta nueve cuadros entre acuarelas y óleos, que revelan los grandes progresos que ha realizado en sus estudios en Italia y en España, especialmente en el Museo Nacional. Entre sus trabajos sobresalen una acuarela titulada 'Un obispo', una tabla al óleo 'Plaza de los jesuitas en Nápoles' y un lienzo de poco más de un metro titulado 'Recuerdo de aldea'. Distínguense estas pinturas por la brillantez del colorido y la valentía de la ejecución superiores, sin duda, á la corrección del dibujo" ("Notas de la Quincena", en La Ilustración Sud-Americana, tomo 1, año 1, número 3, 50). La crónica se servirá de las pinturas de Emilio Caraffa, Marcoartú y J. Soler para desplegar la habitual aversión dariana hacia el color local.

47 Santiago A. Calzadilla (1806-1896), compositor musical, uno de los primeros críticos líricos que se dedicó al oficio con asiduidad en la prensa argentina. En 1891 publicó un tomo de memorias sobre la sociedad de su juventud titulado Las Beldades de mi tiempo, cargado de anécdotas porteñas de tono humorístico y célebre en la época de su aparición. Algunos de sus capítulos aparecieron en La Nación, en la sección "A pesca de noticias". 
El señor Caraffa ha recargado un poco el colorido. Su inglés, además, es un inglés de zarzuela, más o menos, Juarez o Gil; su cuadro, en conjunto, no es prueba de amor a la nobleza y grandeza del arte. Habrá quienes le aplaudan: los amigos del asunto nacional, los partidarios de un soñado arte minúsculo y propio, los gustadores del sabor de la tierruca, los que creen el universo tan solamente lo que abarcan sus ojos. ¡Tenga cuidado el artista! Esos son los mismos que quieren convertir a Tamagno en Güemes, hacer saltar a Beruti desde la estepa a la pampa, y hacer brotar de la boca de Camila O'Gorman gorgoritos en italiano. No escuche las falsas enseñanzas del localismo y, pues lo puede, sirva con honradez, si no con pasión, al arte integral y soberano.

El señor Marcoartú firma La salazón del tasajo. La escena pasa en uno de esos grandes establecimientos de salazón; unos cuantos trabajadores están en su tarea, entre montones de carne y sal. Hay algún estudio de movimientos y proporciones. El color no llama la atención. Causa sorpresa la limpieza de esos saladores: no hay una sola gota de sangre, no hay una sola mancha en las ropas. Las carnes muy estudiadas. Carne de buey. ¡Apenas servida por Rembrandt...!

Un cuadro firmado Soler, Sin amparo. El marido ha muerto. La luz que penetra por una ventana ilumina el fondo, en donde está tendido sobre un catre el cadáver, cuya cabeza está oculta por una pobre cortina. La esposa, de rodillas, con un desolado gesto, parece que llora; pero si os fijáis bien, no encontraréis un verdadero dolor en esa máscara. El niño que se abraza a ella comenta, mejor que el aspecto de la madre, lo patético buscado. La entonación de las carnes del cadáver ha sido bien encontrada y el autor no ha dejado de hacer estudios del claroscuro, el cual puede ser desdeñado tan solamente por los que no saben su arte. No lo tome a mal el señor Soler si le aseguran que una de las cosas que forman el mérito de su cuadro es una naturaleza muerta: vea el espectador los accesorios que están en la mesa de la derecha, cerca de la ventana que da paso a la luz.

El artista indio tallando el Cristo de la Merced -otro cuadro tradicional de Ballerini. Cuéntase -y uno de los Dres. Quesada ha escrito la tradición, si mal no recuerdo- que un indio analfabeto, allá en tiempos lejanos, esculpió, guiado por un arte infuso, el Cristo conocido en Buenos Aires con el nombre de Cristo de la Merced. El indio Manuel era un privilegiado, amado de Dios, como el humilde Juan Diego, su hermano mexicano. Ballerini ha escogido el momento en que el indio escultor trabaja en la sacristía del convento, delante de dos frailes. Al pintar uno de ellos, ha tenido la obsesión del mate... Reconociendo las dotes del autor, no encuentra uno, sin embargo, en esa composición, la elección requerida para un asunto que a un artista de vuelo podía ofrecer muchas ventajas. No hay que olvidar que todo lo que es tocado por el aliento de la religión adquiere una vida extraña y superior desde ese instante.

De señalarse son dos obras de Orlandi ${ }^{48}$ : la una, En tiempo de paz. Un enfermo soldado; cerca de él su madre. Él yace en la cama, demacrado, casi moribundo. Ella, cerca de él, le

48 Nazareno Orlandi (1861-1952), pintor italiano de tendencia academicista, nacionalizado argentino. Sus trabajos más reconocidos pertenecen al campo de la decoración edilicia, con obras importantes en la capital porteña como los murales de El Ateneo Grand Splendid, la Iglesia del Salvador y la Iglesia de San Telmo. Fue, además, el encargado de las pinturas del "Salón Dorado" en el nuevo edificio -Avenida de Mayo 575al que el diario La Prensa mudó su sede en 1897. 
tiene asida una mano entre las suyas y le mira con una profunda angustia maternal. El fondo es oscuro. Hay equilibrio; la composición produce su efecto emocional; dos personajes constituyen el poema. La color de la facies, la cianosis, está perfectamente hallada; y da al rostro de agonizante su nota lívida, sobre la gama de los blancos del cobertor. De desearse hubiera sido que se suprimiesen algunos detalles, acortando el cuadro, en el cual, por aumentar las ropas, se ha alargado la cama, de manera que parece interminable. Y luego, ¿a qué distraer la mirada del espectador con ese penacho de bersagliere que aparece debajo del lecho? ¿Para darnos el detalle nimio de que el enfermo es bersagliere? En el rostro de la anciana habría también algún defecto que señalar; pero, en resumen, el cuadro es digno de atención.

Lo mismo que el otro, una tablita que por muchos conceptos revela a un maestro: Beguina. Sobre un negro fondo, se ven dos cabezas, de un viejo y una vieja: un tipo de vieja inglesa, con su cofia oscura, de largas cintas delanteras; está sentada de frente, apoyada en el espaldar de la silla, el viejo con un arrugado rostro jovial. La seguridad del toque no ha excluido el estudio paciente. Solamente al aplaudir esta obrita y retirarme de ella se me ocurre preguntar: esa vieja, ¿va a tomar un polvo o a dar una limosna?

Y saludaré de paso una encantadora mujercita de Cárcova - un pastel finamente armonizado, en que los colores forman caprichosas y cromáticas combinaciones-: De visita.

«La composición es la cima del arte y su razón de ser», afirma un autor. ${ }^{49}$ Los trabajos de composición presentados en este año, no dudamos que serán superados en el entrante en calidad y en número.

Hay que observar la eterna faz siempre nueva de la naturaleza; pero la naturaleza sin el pensamiento que la interprete, es nada.

Entre los estudios que un pintor no debe abandonar nunca, el de la composición está en primer lugar. Arte y «oficio» juntos, hacen las obras inmortales.

49 En la supuesta cita Darío parece volver al "maestro" que preside cada una de las entregas de la serie, pues Ruskin vertía conceptos análogos a los que se desarrollan de aquí en adelante en el apartado de Elements of Drawing (1857) dedicado a la "composición" como principio rector del arte: "Componer quiere decir, simple y literalmente, reunir varias cosas, de modo de hacer una cosa, cuya naturaleza y cualidad ellas ayudan a producir. [...] La esencia de la composición es que todo debe estar en un lugar determinado, cumplir un papel intencional, y actuar, en ese papel, ventajosamente para todo lo que se conecta con él. La composición, entendida en este sentido puro, pertenece, en las artes de la humanidad, al gobierno Providencial del mundo. [...] [E]n toda gran pintura, cada línea y color se arreglan para provecho del resto. Ninguno resulta inesencial, por más tenue que sea; y ninguno es independiente, por más forzado. No es suficiente que representen objetos naturales; sino que deben encajar en ciertos lugares, y unirse en determinados grupos armónicos. [...] Y se debe recordar que el don de la composición nunca le es dado a más de un hombre de cada mil; en su rango más alto, el don no ocurre más de tres o cuatro veces en todo un siglo" (la traducción nos pertenece). Sin caer en el didactismo ruskiniano -aunque reenviando claramente al Arts and Crafts-, Darío se apropia de su concepción del "realismo" para fustigar el abuso del detalle gratuito, incidental, al que está obligado el cuadro "de género", localista o costumbrista. 
Corot -a quien siempre habrá que nombrar- no llegó a la cumbre de su arte sino después de bregas continuas y encarnizadas con el oficio. Imitó, el también, a la naturaleza, como lo demuestran sus cuadros y ejercicios de Italia. Después, fue su particular «fiat lux», creó su luz propia; y siendo un gran poeta, fue un habilísimo conocedor de lo útil y del medio que le servían para hacer brillar las telas glorificadas por su idea.

RUBÉN DARÍO.

\section{El SALÓN}

$$
\mathrm{V}^{50}
$$

Painting, or art generally, as such, with all its technicalities, difficulties, and particular ends, is nothing but a noble and expressive language, invaluable as the vehicle of thought, but by itself nothing.

Ruskin.

Desfilan las faces sin nombre, hijas del capricho, o copias d'apres nature exornadas por la fantasía. A ti, te conozco, personita creada por Bouchet ${ }^{51}$ para la venta, cocotte que te has quitado la máscara, sin saber que tus tentaciones dejarán impasibles a quienes tengan alguna noción de arte. Tu color es bien encontrado: todo lo que te rodea está imitado de mano maestra; pero no tienes ningún encanto. ¡Qué fastidio! Y sin embargo no lo revela tu cara. Estás sentada, como en espera del comprador: él llegará, pues eres pintura que tiene salida...

${ }^{50}$ La Prensa, domingo 27 de octubre de 1895: p. 5, col. 1-2.

${ }^{51}$ Como en la segunda entrega de la serie, la crónica vuelve a referirse despectivamente al pintor español José Bouchet, vinculándolo ahora no sólo al mal gusto sino a la producción seriada de objetos "bellos" para la venta. Bien podría leerse este juicio como una anticipación del enfrentamiento dariano al materialismo burgués dominante en la pintura española finisecular. En este sentido y a propósito del contrapunto entre Darío y Joaquín Sorolla, Acereda apunta que "en el caso español es visible la pervivencia de una corriente dominante de realismo artístico que reflejaba los valores ideológicos del pensamiento burgués y que tiene en el impresionismo una extensión y/o variedad refinada. Contra esas corrientes de captación instantánea, conformadas también en términos naturalistas, respondió un sector artístico español, espoleado por la impronta del movimiento simbolista europeo. [...] En España, dicha corriente llega muy tímidamente al 'modernisme català' y constituye uno de los fundamentos de la poética que configuró el Modernismo hispánico y en el que se enmarca Darío. Así pueden explicarse los entusiastas comentarios de Darío sobre Santiago Rusiñol en España contemporánea (1901), y su mutuo acuerdo en la visión del arte como algo superior, encaminado a la belleza a través de la meditación sobre lo trascendente" (2003: 126). 
Como ejecución eres preciosa, sobre tu canapé carmín, cerca de tu gran tibor. Pero tu cara oh, bien sabes cómo es la galantería de la crítica- es un tanto vulgar. ¡Si tuvieses la de tu vecina hecha a fuego! Mas tenlo sabido: te comprarán, mujercita de carnaval, de traje rosa, dominó celeste y abanico verde, que has nacido al influjo de la moderna escuela española.

Ripamonte: Al pasar. Un rostro armoniosamente hecho, sobre fondo claro; una muchacha tentadora, mas de un accoutrement que salta a la vista. La coloración muy feliz; el velo que cubre el rostro es real; ipero ese sombrero!...

Del mismo autor son estas dos hermosas mozas tristes: Las huérfanas. Es una obra casi irreprochable. Cuadro trabajado con conciencia y que indudablemente ha sido ideado, al principio, de una sola figura. Es una de las más aplaudidas obras del Salón.

La señorita de Iglesias ${ }^{52}$ ofrece una figura que tiene nombre. Su nombre es Angélique y su familia, Rougon Macquart. Es aquel lácteo lirio que hizo Zola brotar un buen día en el terreno muy bien abonado de su ciclo de novelas. Angélique, la heroína de Le Réve, está representada en este cuadro, en la mañana en que aguarda a su novio ideal. Está sentada, con un ramo de violetas en las faldas, junto a una mesa en que la luz de una lámpara lucha con la invasión del alba. Es un cuadro de tonos apagados. ¿Diremos que hay en la autora una completa inhabilidad para pintar? Sí; pero adornaremos nuestro decir con esta afirmación: la autora comprende el arte: tiene talento. En su trabajo vemos que ha andado aquí, allá, la mano del maestro, de Sívori. Han podido así suavizarse algunos defectos.

De Sívori es Aurora mundana, juegos de colorido, oposiciones de luz; una mujer, perfilada; parece que se retirase de una fiesta. La faz está alumbrada por luz artificial; tras ella baja el día y la baña también con su claridad. Es una rubia, muy rubia. El cuadro es de ejecución complicada; una griserie. Su autor lo define así: «Es una copa de champaña artística». Dios mío, y lo cierto es que la vista se embriaga en esa amable danza de colores alegres.

Otro discípulo de Cárcova, Maggiolo ${ }^{53}$, tiene una desagradable mujer azul sobre un fondo de peluche rojo oscuro: a este pastel se opone otro suyo, Las violetas, superior en grado sumo. Una dama de maduros años escoge una violeta: he ahí el sencillo asunto. Mas el trabajo es bastante plausible, y en él Maggiolo da a entender que es un buen discípulo de su maestro: muchas de las cualidades de éste están allí demostradas. Es en fin un bravo estudio de colorido en que se ha probado también grande agilidad en la ejecución.

Craintive, es un Schiaffino de 1889. Sobre fondo sombrío, el perfil de una joven; un lindo color pálido, ojos brillantes y ardientes, cara de histérica. Temerosa... ¿de qué? Lo más probable es que tenga el temor de las consecuencias de sus infidelidades. Hay perfidia bajo el cristal de esos ojos.

Lejos está hoy el autor de su primera manera: pero ¿no podría, al aumentar su ciencia, conservar ese encanto de las pasadas obras?

${ }^{52}$ Las dificultades para estudiar la obra de las artistas mujeres constituyen un lugar común en los diccionarios e historias del arte especializados en el fin de siglo argentino y latinoamericano. En este caso -así como en el de la pintora Delia Humerez, mencionada unos párrafos más adelante- nuestra investigación no ha logrado dar con algún dato significativo.

53 Javier Maggiolo (1875-1956) se destacó como pintor en la vertiente del realismo social, línea que cultivó en sintonía con el "maestro" al que remite la crónica. 
La señorita Delia Humerez, discípula de Della Valle, ha querido encarnar la tentación femenina, en su cuadro Provocación. Sobre un cojín rojo se levanta la cabeza de una mujer hermosa y fresca, con un aire y sonrisa de encender la sangre. No tenemos ocasión de felicitar a la autora por el dibujo en general, y menos por el ramo de flores que está colocado en el corpiño de su carnal y sonrosada figura. Es un cuadro de efecto, pero que no resiste el análisis.

La bacante de Della Valle, la actitud que tiene, no provoca, según mi entender. Es una gozadora de la vida, y sonríe, en medio del goce. La bacante de Dresco dice que no la ha visto nunca en Grecia. Es la pintada una bacante modernísima, que tiene su precio; y podría, por ejemplo, llamarse Nana, o simplemente Lola.

Opongamos a esta fuga sensual, a esta violencia cantaridada, una cabeza de mujer, llena de distinción y de calma, de Orlandi. Es trabajo magistral, aunque un tanto vieux jeu, pues ha hecho su cuadro el autor con un verdadero derroche de bitume. Mas es una obrita seria y acabada, de lo mejor que se expone este año.

Cárcova ha dado vida a un calvo anciano barbudo, que surge de osadas blancuras, cubierto con un ropaje también blanco. El rostro escorzado, la barba vieja quebrada sobre el pecho, las espesas cejas, toda la fisonomía está perfectamente comprendida y manifestada, y muestra Cárcova una vez más su conocimiento del dibujo y sobre todo, su amplio y fuerte dominio del color.

Al pasar, encuentro otra obra de Maggiolo, una cabeza de estudio. Cabeza de señora de cierta edad, respetable, y que os parece haber visto ya en alguna parte. No os equivocáis; es la misma dama de las violetas. Asimismo, podéis ver una cabeza de niño, de la señora de Martinto $^{54}$, de una agradable y tamizada entonación gris. Y ahora quédome en frente de una obra que siendo obra pictórica, entra en el imperio del arte literario; una pintura intelectual: Lady Rowena, por Eduardo Schiaffino.

El poeta dice:

Fleurs sur fleur! Effeuillez des fleurs! Que l'on promène

Des encensoirs fleuris sur le tertre où, là-bas,

Dort Ophélie avec Rowena de Tremaine. ${ }^{55}$

Ya sabéis, aquella Lady Rowena de Tremaine, en cuyo cuerpo miró el enamorado brillar nuevamente, por el sacro milagro del amor, los ojos celestiales de Ligeia. ${ }^{56}$

${ }^{54}$ Crescencia Obligado de Martinto (1853-?), esposa del "bibliófilo-poeta” mencionado más adelante, Domingo Martinto, y hermana de uno de los contendientes de Darío en el Ateneo, el nacionalista Rafael Obligado.

${ }^{55}$ Quinta estrofa del poema de Laurent Tailhade, "Les fleurs d'Ophélie" (Vitraux, 1891). Darío había publicado -además de la semblanza de este raro en la que reseñaba su Vitrauxuna versión en prosa del poema, junto a otras traducciones de Verlaine, Barbey d'Aurevilly, de la Villehervé, Corbel y Mallarmé (en el artículo mencionado previamente, "Fiestas primaverales. Los poetas y las flores"). Transcribimos la versión dariana de la estrofa: "¡Flores sobre flores! ¡Deshojad flores! Que se paseen incensarios floridos, sobre la tierra en donde, allá lejos, duerme Ofelia con Rowena de Tremaine". 
¿Ha logrado Schiaffino evocar la faz de la misteriosa Rowena? Recuerdo que entre los artistas que han ilustrado la obra de Poe, uno de Francia -Chifflart, Jean-Paul Laurens, uno de los que ilustraron la edición de Quantin de «Los cuentos extraordinarios»- interpretó la extraterrestre figura. ${ }^{57}$

La pintó en el lecho, en el momento en que la nostálgica y enamorada alma de la antigua adorada, llega a calentar el ajeno nido material abandonado. Es un tema espectral y el artista consiguió su objeto, dando con su obra la idea de una aparición.

Pero el dibujo, el aguafuerte, el blanco y negro en fin, tiene recursos apropiados al caso, muy superiores ciertamente a los de la pintura. La pintura, con sus coloraciones y vitalidades, dificulta la sugestión del ensueño.

No podemos imaginarnos que esas hijas divinas del Misterio, tengan un cuerpo sexual como todas las mujeres, sangre y carne y cabelleras que vemos todos los días. Y he allí lo que acrecienta el valor de esa cabeza de Schiaffino.

Con los recursos del óleo, con el acertado empleo del claro oscuro, con calculadas ligerísimas deformaciones, ha hecho surgir del fondo nocturnamente opaco de la tela, una Lady Rowena, una rara y animada flor de ensueño.

Desnoyers escribió la palabra «spirite», al referirse a La fille blanche de Whistler. Y agrega esta frase: "C'est tout à la fois simple et fantastique, le visage a une expression tourmentée et charmante qui fixe l'attention». Ello podía aplicarse a la Lady Rowena del Salón. Y sobre todo, las palabras que siguen: «Hay algo de vago y de profundo, en la mirada de esa joven que es de una belleza tan particular que el público no sabe si debe encontrarla fea, o linda». ${ }^{58}$

${ }^{56}$ El cuento de Poe recogido en Tales of the Grotesque and Arabesque (1840) fue publicado por primera vez en la revista American Museum, el 18 de septiembre de 1838 . Darío traducirá fragmentos del relato -a partir de la versión francesa de Baudelaire en Histoires extraordinaires (1856)- en la serie de crónicas titulada "Edgar Poe y los sueños", que aparece en La Nación entre mayo y julio de 1913.

${ }^{57}$ Se trata del aguafuerte de Johann Wögel que acompaña la traducción baudelaireana de "Ligeia" en las Histoires extraordinaires (Paris, A. Quantin, 1884, 285). Al retrato de Poe por François-Nicolas Chifflart, que figura en las primeras páginas de este tomo, se había referido Darío en su ensayo "Edgar Allan Poe" (Revista Nacional, Buenos Aires, segunda serie, año VII, tomo XIX, 1 de enero de 1894; recogido en la primera edición de Los raros). Jean-Paul Laurens diseñó el heliograbado que ilustra "Le portrait ovale" de las Nouvelles histoires extraordinaires editadas por A. Quantin, también en 1884.

${ }^{58}$ Las citas pertenecen al tomo de Fernand Desnoyers, Le Salon des Refusés. La peinture en 1863, Paris, Azur Dutil, 1863, 27. Traducimos la primera: "Es a la vez simple y fantástica, la cara con una expresión atormentada y encantadora que reclama la atención". Dice Desnoyers al reseñar la obra culminante del polémico Salón de 1863: "La peinture la plus singulière, la plus originale, est celle de M. Whistler. La désignation de son tableau est: La Fille blanche. C'est le portrait d'une spirite, d'un médium. La figure, l'attitude, la physionomie, la couleur, sont étranges. C'est tout à la fois simple et fantastique. Le visage a une expression tourmentée et charmante qui fixe l'attention. Il y a quelque chose de vague et de profond dans le regard de cette jeune fille, qui est d'une beauté si particulière, que le 
Tiene, en efecto, Lady Rowena, en medio de su penumbra, una belleza especial, una belleza que se podría decir triste.

En esa mujer miráis un no sé qué de la sonámbula, de la iluminada, de la que tiene algo del más allá. Corresponde a una verdadera evocación de médium, como la Katie de Crookes. $^{59}$

Repito que en mi parecer es una obra pictórica que confina con las letras. ${ }^{60}$

Esta interpretación augura una buena labor del mismo Schiaffino, en idéntico terreno, pues se prepara a ilustrar, junto con de la Cárcova, algunos poemas de Poe, que publicará en breve traducidos al español Leopoldo Díaz. ${ }^{61}$

public ne sait s'il doit la trouver laide ou jolie. Ce portrait est vivant. C'est une peinture remarquable, fine, une des plus originales qui aient passé devant les yeux du jury" (27-28).

59 William Crookes (1832-1919), físico y químico inglés, estudió y documentó a principios de la década de 1870 la materialización de un ectoplasma que decía llamarse Katie King y que surgía a instancias de la médium Florence Cook. La investigación de Crookes -"Notes of an Enquiry into the Phenomena called Spiritual during the Years 18701873", publicada en el Quarterly Journal of Science en 1874- participaba de las intensas polémicas por el estatuto científico del Espiritismo, en un intento por legitimar la disciplina.

60 Esta valoración de Schiaffino será muy resistida por los antagonistas de los "modernos", sobre todo por aquellos que se sintieron excluidos de las prerrogativas del Salón. Las repercusiones en otros periódicos porteños no se hicieron esperar. El 6 de noviembre de 1895 aparecía en El Correo Español el artículo "Una visita al Ateneo" firmado con el seudónimo Licenciado Veritas, en el que se combate la perspectiva dariana sobre Schiaffino al tiempo que se reivindican las figuras de los "extranjeros" cuestionados o minimizados por la serie (Bonifanti, Bouchet, Paolillo, Parisi): "Lady Rowena (Edgar Poe) Nota negra. Todos esos nombres tiene el cuadro número 36, de que es autor Eduardo Schiaffino. La primera vez que le vi me pareció una cosa muy mala, si no como idea, porque en él no encontré ninguna como ejecución. Pero leí los artículos que le dedicaron los doctos de los grandes periódicos ó, mejor dicho, periódicos grandes y todo medrosico y avergonzado volví al Ateneo, seguro de que, fijándome bien, saldría de mi error, y ya que no pudiera apreciar toda la sublimidad de esa obra magna, que eso se reserva para los señores superiores, al menos vería algo bueno de ella, algo que me revelara aquella pintura literaria de la que hablaba el docto de uno de tales periódicos. Y no fué completamente perdida mi segunda visita, después de examinarla bien, me pareció peor. [...] Se asegura que ese cuadro encierra un pensamiento muy profundo y que la mujer que en él aparece 'es una belleza triste'. Yo la encuentro de una fealdad repulsiva y no veo la menor semejanza entre ella y el personaje de Edgar Poe. No dudo que el pensamiento de pintor haya sido representar esa mujer, ni que haya puesto su mejor voluntad por conseguirlo. Pero de buenas voluntades está empedrado el infierno y en el arte no escasea, por desdicha, esa clase de adoquinado" (2).

${ }^{61}$ Para este proyecto conjunto - que termina hasta cierto punto malogrado- ver Malosetti Costa (2001: 321 y 385) y García Morales (2004: 125). Darío se refirió varias veces al tomo en preparación de Leopoldo Díaz - muchas de cuyas traducciones ya habían aparecido en la prensa periódica-, volumen que termina publicándose recién en 1897 (Buenos Aires, Pablo E. Coni e Hijos), sin las ilustraciones y con versiones de otros poetas además de las de Poe 
Bien halla el artista que busca su campo en la altura. Mientras los espíritus reflexivos y exquisitos padecen bajo las avalanchas de lo real, y en filosofía, en literatura, en arte, se presenta la innumerable falange de los enemigos de la sagrada Psiquis, hagan los pocos amadores del ideal la defensa del alma.

Esa Lady Rowena de Schiaffino habría dado a este respecto la nota más alta del Salón, si no hubiese expuesto sus cuadros una mujer, Diana Cid García, la cual, lector, misteriosa, suave, enigmática, llena de visiones y de sueños, en su vago aislamiento, nos espera. ${ }^{62}$

RUBÉN DARÍO.

\author{
EL SALÓN \\ $\mathrm{VI}^{63}$
}

Painting, or art generally, as such, with all its technicalities, difficulties, and particular ends, is nothing but a noble and expressive language, invaluable as the vehicle of thought, but by itself nothing.

Ruskin.

Las ásperas brutalidades de la existencia actual, las infamias de la política, la general consagración a faenas prácticas y al culto del negocio que ha desarrollado la vida contemporánea, el descenso de la literatura al análisis de las bajezas y miserias del animal humano; la prostitución de la fama por los leones del periodismo; la necesidad de una renovación, de una revolución contra el pontificado de la banalidad, impulsaron a ciertos espíritus de excepción ${ }^{64}$ a la busca de formas no usadas, al abandono de los procedimientos

(Leconte de Lisle, Victor Hugo, José María de Heredia, Sully Prudhomme, Henri de Régnier, Émile Zola, Gabriele D’Annunzio, Lorenzo Stecchetti y Guerra Junqueiro).

${ }^{62}$ La crónica se cierra con un calculado golpe de efecto que refuerza la expectativa ante la "figura estelar" de la serie. Darío escribe Diana "Cit" García, error que corregimos a partir de la esforzada reconstrucción biográfica desarrollada por Malosetti Costa (2001: 385390).

${ }^{63}$ La Prensa, viernes 1 de noviembre de 1895: p. 4, col. 5-6. La penúltima entrega de la serie dedicada al Salón del Ateneo destaca por la singular exposición del ideario estético dariano, anticipo en el plano "pictórico" de las operaciones que un año después -con la publicación de Los raros (1896)- se pondrán en juego en el terreno de las elecciones literarias. En este sentido señala García Morales que "junto al canon de escritores «raros» que venía exponiendo en la prensa desde su llegada, [Darío] estaba elaborando otro canon equiparable e interrelacionado, aunque menos estructurado y casi secreto, de pintores «raros»»" (2004: 124).

${ }^{64}$ Darío se apropia de la categoría de espíritu, artista o literatura "de excepción" -y la incorpora a su léxico crítico con frecuencia- a partir de los trabajos de Vittorio Pica (1862- 
establecidos, al irrespeto de los cánones normales, a la autominería de las propias almas, a la persecución de ideales nuevos, o a atrevidas exploraciones y renovaciones en los antiguos bosques de la Historia. En el terreno artístico, a tal movimiento corresponde la manifestación de ciertas doctrinas vistas con escándalo por los mandarinatos oficiales, la creación de escuelas, cenáculos, capillas, grupos y sub-grupos hoy casi desaparecidos, pero que han servido para el fundamento y desenvolvimiento de la individualidad en el arte modernísimo. En la lucha, los que han ido armados de una real fuerza, caparazonados de verdadera fe, casqueados de noble altiveza, han triunfado y viven en su obra. Los desprovistos de esenciales condiciones, los pannurgistas, los snobs, los débiles, han muerto, y con ellos sus tentativas y sus homúnculos.

Siguiendo el impulso y el ejemplo de los poetas, los pintores y dibujantes tendieron sus miradas por espacios desconocidos, ya iniciando una nueva y robusta comprensión de la naturaleza, ya envolviéndose en la bruma del ensueño, investigando en países del misterio, circunscribiéndose a la sensación o penetrando en un alba perpetua de luces místicas, violentos hasta el dislocamiento, o sutiles hasta la intangibilidad, celestes hasta el éxtasis o satánicos hasta la posesión; confundidos maestros geniales con imitadores inconscientes, sublimes soñadores con sonoros charlatanes; unos encarnizados en la caza de la línea hasta sus más íntimas combinaciones, apasionados del grotesco y arabesco; otros haciendo de la nobleza y pureza del dibujo la base única de la creación artística; otros desdeñándolo todo por la idolatría del color; otros formando un concubinato de arte y ciencia; otros sembrando en la sombra flores de visión, arquitecturas de sueño de opio, animando en una niebla indecisa figuras hípnicas, pintando la alucinación y la pesadilla, juntando a Durero con Poe, o imaginando combinaciones simbólicas y arcanas; líricos o matemáticos, babilonios o persas, japonenses o tahitianos; befados por unos, incensados por otros; clasificados por la ciencia representada en la persona del ínclito judío Nordau, ese Tribulat Bonhomet de la sabiduría universitaria ${ }^{65}$; y de ese maremágnum surgieron las distintas estampillas que se aplicaron a los diversos grupos de novadores: impresionistas, neo-impresionistas, tradicionistas, neo-tradicionistas, cromo-luminaristas, deformadores, simbolistas, místicos e independientes.

Por reacción contra la animalidad, unos se eternizaron, y a los cuadros llameantes o hemorrágicos, opusieron los cuadros de luces tamizadas, de neblinas transparentes y huyentes; se recordaron nombres de artistas olvidados en lo hondo del tiempo, se retrocedió a la primitividad; se llegó hasta hacer de la ignorancia una cualidad, y a imitar a los

1930), el principal introductor del simbolismo francés en Italia. García Morales apunta al respecto que "Darío seguía la obra de difusión de nuevos valores cosmopolitas de Vittorio Pica desde al menos 1896. Su ensayo sobre el portugués Eugenio de Castro para Los raros tiene como una de sus principales fuentes la traducción que Pica hizo ese año al italiano de Belkiss de Castro" (2006: 51).

${ }^{65}$ Darío había publicado su primer descargo contra Max Nordau en La Nación, el 8 de enero de 1894: "Manicomio de artistas. Degeneración. La última obra de Max Nordau". Enfrentado al famoso crítico y también columnista de La Nación-que aquí es comparado con Tribulat Bonhomet, "el asesino de cisnes", personaje del libro homónimo (1887) de Villiers de l'Isle-Adam-, Darío sostendrá con él, pocos años después, una de sus más intensas polémicas. 
bizantinos y a los antecesores de Memling, en los defectos en que incurrieran por el estado del arte en su época. Los prerrafaelitas ingleses y sus precursores alemanes fueron superados en atrevimiento de tendencias. Por otras vías Redon se hunde en el sueño y en el misterio de la sombra; Rops se complace en negro-y-blancos milenarios, llenos de muerte, o en apariencias obscenas o macabras; Moreau orientaliza sus sueños en suntuosas telas; los maestros quieren poseer la Luz por modos distintos; Manet se había preocupado después de Delacroix de obtener, según la palabra de Germain, por una rudimentaria división del tono, el color en la luz; Puvis de Chavannes la busca en el claro difuso; los tachistes siguen a Manet; hasta las aplicaciones de Seurat que establece la división del tono, sujetándola a la ley de los complementarios. Los deformadores proclaman la virtud de sus teorías: conservar piadosamente la sensación original y manifestarla por líneas y colores bellamente raros y armoniosos, «pero por medios primitivos y una libertad de interpretación que vaya hasta lo extraño, hasta la deformación: un contorno acortado, poco o nada de modelado, tonalidades extendidas sin degradaciones y hasta sin relaciones de valores». ${ }^{66}$ Etcétera. Oscar Wilde y sus amigos en Inglaterra, el snobismo parisiense, las monerías de los acólitos mediocres, la «moda»; y estamos en plena Kamtchatka...

¿Viene V. de esa recién descubierta península, señorita Diana Cid de García? ${ }^{67}$

${ }^{66}$ Alphonse Germain (1861-1938), impulsor y difusor en la prensa francesa (L'Ermitage, La Plume, Moniteur des arts, L'Art et l'Idée) del simbolismo y el neo-impresionismo, movimientos que encontraban el artista "modelo", según su perspectiva de un elitismo hermético, en Puvis de Chavannes. En el transcurso de la década de 1890 Germain recogió y publicó sus artículos en varios tomos como Notre art de France (1894) y Du beau moral et du beau formel (1895). Darío glosa, en el primer segmento del párrafo, el capítulo "Le chromo-luminarisme" del libro Pour le beau: essai de kallistique (Paris, E. Girard, 1893): "La lumière, hantise des peintres contemporains, Puvis de Chavannes, décorateur inné, la chercha par le clair diffus; tandis que Manet, plus peintre, tentait, après Delacroix, d'obtenir par une rudimentaire division du ton la couleur dans la lumière" (21). Y luego traduce libremente del titulado "Les déformateurs": "Désorientés par l'exotisme, dont ils s'assimilent moins l'esprit qu'ils ne pastichent la lettre, les autres novateurs, —à prétentions idéistes et décoratives, - rejettent, avec une sérénité inconsciente, perspective, modelé, dégrations de teintes, valeurs de tons, et, donnant aux jeux de lignes une signification conventionnelle, déforment jusqu'à la laideur sous prétexte de synthétiser et de conserver la sensation originale" (37).

${ }^{67} \mathrm{La}$ crónica ha construido, hasta este punto, todo un entramado de firmas del arte moderno -al que agregará algunas más, aproximándose a la estética simbolista aunque sin terminar de identificarse con ella-, para proyectar sobre esa escena la figura de la singular "pintora viajera", la inesperada estrella de la exposición. No es difícil leer en el gesto del saloneur una decidida provocación, que va mucho más allá de la exhibición de un canon pictórico "raro", pronto estigmatizado en la Buenos Aires de ese entonces con el epíteto de "decadente". Por un lado, si en las entregas previas había distribuido -entre ironías sutilestibios elogios a los artistas afines al modernismo y a los ya consagrados -Schiaffino ante todo, también de la Cárcova y Sívori-, ahora Darío levanta a una desconocida, que ha pasado desapercibida en el Salón y que rápidamente será olvidada. Por otro, formada en París y contra lo que podía esperarse en este horizonte, la joven "promesa" del arte 
No hay duda de que su barca de viajera se ha detenido por allí; pero ha permanecido también un buen tiempo en la isla encantada en que hoy está ya consagrada para siempre, con su luz melodiosa, y su especial visión, la figura del insigne decorador, del maravilloso poeta, del gran Puvis. En él ha aprendido V. a amar la flexibilidad de las bellas líneas, los grises tímidos y adorables, las atmósferas dulcemente visionarias.

Lector que visitas el Salón, detente unos instantes delante de las obras de esta artista, colocadas sobre la cimaise ${ }^{68}$ por los jueces del mérito. Oh, ella no es Kamtchatka, aunque haya visitado la península; el hijo de Alfonso Daudet no le lanzaría una sola de sus flechas.

Esta señorita argentina ha vivido en París en indudable contacto con intelectuales; conoce maestros verdaderos y legítimos Kamtchatkas; ha sido tentada por los duendes del simbolismo; pero, cuando ha debido trasladar su pensamiento a la tela, ha preferido seguir las huellas de Puvis de Chavannes que, si no es simbolista, es genial.

$\mathrm{Y}$ como a los poetas principiantes les acontece no tener rumbo fijo, y vacilar, y mirar hacia este o aquel maestro liróforo, a ella acontécele no solamente fijarse en Puvis, sino también volver el rostro a otros artistas magistrales, por ejemplo Grasset.

De un vitrail de este egregio maestro procede sin duda alguna la Morphine de Diana Cid de García. La cual tela es un Grasset que ha leído Rollinat y es amigo de Des Esseintes. ${ }^{69}$

argentino es una mujer. Malosetti Costa destaca que "Darío fue una excepción en cuanto a su aproximación crítica a las mujeres artistas. En general ellas eran agrupadas con displicencia y mencionadas como 'aficionadas' o 'distinguidas damas', 'señoritas', alumnas de tal o cual pintor. El nicaragüense no hizo distinciones de este tipo y trató las producciones femeninas sin distinciones de género, colocándolas en el mismo rango que las de los varones" (2001: 385).

${ }^{68}$ El "cimacio" es vocabulario de la arquitectura para designar la moldura que corona un pedestal: un modo de aludir a la mención del jurado que recibió la obra de Diana.

${ }^{69}$ Darío hace gala de su biblioteca en una nueva modulación del motivo del ut pictura poesis que le permite explicar la obra decididamente decadentista de Diana. A dos días de publicar su irónico descargo contra la valoración dariana de la Rowena de Schiaffino, el Licenciado Veritas volvía al Salón en un planteo que exhibe el carácter insólito difícilmente asimilable en el entorno porteño- de esta operatoria: "Lector querido, que aceptas con benevolencia mis palabras, ¿no es cierto que la terminación de mi anterior artículo te hizo esperar, ó para hablar más claro, temer una larga digresión sobre las diversas tendencias innovadoras y sus diversos representantes los impresionistas y neoimpresionistas, tradicionalistas y neo-idems, cromo-luminaristas, deformadores, simbolistas, místicos, mistificadores y macaneadores? Di, ¿no viste en mi promesa de tratar aisladamente las obras de Diana Cid de García envuelta una amenaza de lata alevosa en la que con rebuscado estilo é intercalando gran copia de nombres de pintores más o menos conocidos y no menor de frases y aun párrafos en francés, inglés, sánscrito ó caló, viniera á parar en que ni tú ni yo supiéramos lo que quise decir? Pues si tal cosa pensaste, desecha tu miedo, porque no es ni ha sido mi intención mostrarme ante tí erudito -con la ayuda del Larousse o de cualquiera otra enciclopedia más moderna- sino simplemente hacer algunas observaciones á la señora o señorita autora de los cuadros en cuestión y á cuantos como ella, por efectos de una torcida educación artística y arrastrados por un irreflexivo amor a todo lo nuevo, tratan de salirse del camino recto para tomar por sendas extraviadas y sin salida" 
He aquí el cuadro ${ }^{70}$ : sobre un fondo de rojo viejo, estrellado de oro pálido y apagado, entre grandes amapolas sangrientas de verdes tallos, está una mujer de perfil, casi hieráticamente, vestida de negro, cubierta la cabeza con un velo negro, la faz pálida. Da la sensación de una mujer espectral que ocultase bajo sus formas enigmáticas, casi religiosamente icónicas, una perversidad sacrílega y misteriosa. Es una mujer que inquieta. Una mano maestra, que aparta el velo; es una mano delgada y huesosa;

\section{Elle était si maigrelette... ${ }^{71}$}

Es una concepción finisecular y venenosa: sugiere la sensación de picadura de la Pravaz $^{72}$, de las lentas muertes engañosas, de las evasiones a los paraísos artificiales, a cualquier parte fuera de este feo mundo: anywhere out of the world! $!^{73}$ Engagée, cartón de vitrail de Grasset, es el inspirador; la artista ha procedido después, fuera de la idea original, según la concepción de su asunto. En Engagée está el busto entre las flores, en idéntica disposición; en vez de ser perfil, son tres cuartos; el hieratismo es el propio; el detalle de la mano es casi idéntico.

Un pastel hay, en que se representa a una mujer medieval, siquiera fuese moderna medievalizada; coloraciones tenues; los indispensables bandeaux Botticelli; vestido de viejo tafetán verdoso; los ojos bajos, la boca grande y sensual.

En Meditación, sobre una barca rústicamente construida, en un país legendario, en un agua blanca entre espadañas y yerbas acuáticas, una mujer, de pie, está con los brazos cruzados.

Es una visión, al hablar de la cual han nombrado el Pobre pescador de Puvis.

("Una visita al Ateneo - Un poco de morfina - Siga la broma", El Correo Español, 8 de noviembre de 1895,2 ).

${ }^{70}$ El texto avanza sobre un eje que atraviesa la poesía y el poema en prosa modernista, pero ahora desde el terreno de la "crítica de arte": la "écfrasis", la representación verbal de una obra de arte visual. A partir de la crítica que instala Baudelaire en sus Salones, el motivo del ut pictura poesis deviene en la modernidad un medio que permite alcanzar metas literarias, es decir, una vía para crear sobre los márgenes de los dos campos implicados, el de las letras y el de la pintura. Cabría preguntarse, entonces, qué "ven" las descripciones darianas en los cuadros de Diana Cid: fantasmas, figuras difusas, translúcidas, huidizas. Lejos de la voluntad de restitución o copia de un pleno-original, la crítica toma a la pintura y aquí el signo de la écfrasis en la crónica- como un pretexto para fundirse con su objeto, para volverse ella misma "poesía", "literatura".

71 "Ella era tan flacucha..." El verso pertenece al poema "Mademoiselle Squelette" de Maurice Rollinat (en Les Névroses, 1883).

72 Charles Gabriel Pravaz (1791-1855) fue el inventor de la jeringa hipodérmica, instrumento al que alude el texto.

${ }^{73}$ La expresión inglesa la cita Poe en "The Poetic Principle" (1850) al reproducir el poema de Thomas Hood, "The Bridge of Sighs". Baudelaire traduce ese mismo poema en 1865; y coloca esa frase, en 1867, como título de uno de sus "poemas en prosa", luego recogido en Le Spleen de Paris (XLVIII). 
La Visión blanca va entre flores, pintada de viejo retablo. La visión blanca, una novicia o doncella inocente, cuyo peinado no tenía ya que preguntar cuál es, va entre flores que se yerguen sobre sus largos tallos, como todas las flores de los místicos.

Floriferaria es una linda niña rubia que, como el título del cuadro lo indica, lleva flores. Los duendes de la deformación guiaron aquí el pincel de la señorita Diana, y el cuello lilial, para poder merecer ese adjetivo, se ha estrechado teratológicamente.

Hespérides representa en un parque solitario una mujer de ensueño, alta y delgada, vestida de blanco, con un chal violeta que desciende por sus flancos descuidadamente. Pálida, con el pecho sin opulencia, casi insexual, está bajo un naranjo -y aquí aparece otra vez Grasset, con su vitrail de L'Automne, ejecutado por Gaudin, y que por más de un punto tiene semejanza con la obra de Diana.

El dúo es un cuadrito de tema moderno. Ha aplicado los mismos procedimientos empleados en sus obras anteriores, ya citadas, a una escena común de cualquier vulgar habitáculo contemporáneo. Una señorita Botticelli está sentada al piano. Cerca de ella está de pie otra señorita igualmente Botticelli. Ambas, melancólicas y soñadoras, viven en un ambiente blando y en una luz opaca; ambas, al amor de la música, sueñan. Se trata, indudablemente, de algo de Grieg, u otro músico escandinavo. Es una escena de pleno kamtchatkismo...

Pensativa, es un retrato de la autora, según se sabe. Ojos azules, rubia, boca fina y pequeña, es una mujer frágil, delicada, vibrante, arpa de nervios.

$\mathrm{Su}$ cabeza parece como una rosa tenuemente rosada, sobre el ropaje negro, de gorguera ribeteada de blanco.

No analizaremos, lector, mi amigo. Sólo habrá que decir que en todos los cuadros el arte ha puesto su sello. La que ha pintado esas cosas, es «alguien». Ver brotar de un cerebro de mujer semejantes concepciones, en realidad sorprenderá a quienes reconocen la demostrada pasividad cerebral del hermoso sexo. Una mujer, en literatura, ya se sabe los límites que tiene, desde Safo hasta la Pardo Bazán; a menos de una excepcionalidad nativa que produzca una Rachilde, y eso la ciencia y la demonología, cada cual por su lado, saben qué es. En pintura, se creería que la cúspide fuera para ellas las caras obras de Rosa Bonheur, o las vulgares lindezas florales de Magdalena Lemaire. Pero existe una madame Jacquemin ${ }^{74}$, y si Diana Cid García estudiase y se consagrase al arte, -no entra en lo imposible- quizá serían dos.

RUBÉN DARÍO.

74 A diferencia de las dos artistas previas -Rosa Bonheur (1822-1899) y Madeleine Lemaire (1845-1928), proclives a acatar los estereotipos previstos para las pintoras en la época-, Jeanne Jacquemin (1863-1938) fue considerada desde su primera exposición en 1892 "el arquetipo de la mujer y artista simbolista en el círculo de los Peintres de l'âme y espiritualistas Rose-Croix, a cuya sociedad no pudo ingresar por ser mujer, pese a los intentos de Péladan y de Jean Dampt. [...] Significativamente, más tarde Diana Cid se casó con el escultor Jean Dampt" (Malosetti Costa 2001: 385). 


\section{EL SALÓN}

$\mathrm{VII}^{75}$

Painting, or art generally, as such, with all its technicalities, difficulties, and particular ends, is nothing but a noble and expressive language, invaluable as the vehicle of thought, but by itself nothing.

Ruskin.

Lector benigno, siquier prudente, que vas a visitar el Salón, haz con tu amabilidad un ancho cesto - ponle ante todo flores y bombones y abanicos para las manos blancas- y echa en él pájaros, frutas, rosas, claveles, y todas las demás clases de bonitas cosas pintadas que tienen por nombre «Naturalezas muertas»; déjalo con gran tiento y delicadeza a un lado y vamos a visitar a un excelente artista, el señor Félix Pardo de Tavera. ${ }^{76}$

Si algún gran nombre se atreviese a traer a la memoria, al referirse a este español, sería ese nombre el de Grasset, cuyo ingenio recorre todas las fases del arte y halla empleo hasta en lo más diminuto, expandiéndose en el vitrail, como en la ilustración, como en el affiche, o en el pequeño ornamento tipográfico.

El señor Pardo de Tavera expone en este Salón como pastelista, escultor, empastador y pirograbador. De un pastel de suaves tintes, Elena y Susana, pasa a una linda figura hecha a fuego, Ensueño; o a las tapas de un álbum, también a fuego. Este procedimiento, que ha llamado la atención de los visitantes, no tiene sino muy poco tiempo de uso. ¿Quién lo ha inventado? M. Manuel-Perier, de París. Él mismo lo aplicó a trabajos artísticos, como lo dice el rapport, fecha 23 de noviembre de 1888, de la "Société d'Encouragement à l'Industrie Nationale». Se ha afirmado que la aplicación artística de la piroxilografía se debe a M. H. Guérard. ${ }^{77}$

${ }^{75}$ La Prensa, domingo 10 de noviembre de 1895: p. 9, col. 1-2.

${ }^{76}$ Félix Pardo de Tavera (1859-1932), artista español de origen filipino, obtuvo su grado de médico en La Sorbonne en 1882 con una tesis que examinaba las causas de la muerte fetal en los estadios tempranos del embarazo. Casado en 1890 con la argentina Agustina Manigot, emigró poco tiempo después a Buenos Aires -luego de que su cuñado, el pintor Juan Luna (1857-1899), asesinara a su madre y su hermana en un confuso episodio de violencia doméstica- donde fue reconocido, sobre todo, por sus esculturas en bronce.

${ }^{77}$ En 1875 el médico francés Claude Pacquelin inventó una máquina para cauterizar que revolucionó la cirugía de la época. François Manuel-Perier diseñó a partir de esta máquina un instrumento adaptado a las necesidades del artista pirograbador que, a partir de su presentación en la Exposición Internacional parisina de 1899, transformó la técnica en una "moda". Maurice-Henri Guérard (1846-1897), prolífico grabador francés, fue uno de los principales responsables de su difusión. 
Los poetas debemos protestar: no, no sois vosotros, señores, los que habéis descubierto y puesto al servicio del arte el fuego; fue el Padre, fue Hugo, cuando estaba allá lejos, en la Isla.

He aquí lo que ha dejado escrito el secretario de Victor Hugo, Richard Lesclide:

"Victor Hugo, dibujante, tiene recursos de colorista desenfrenado. Trabaja diariamente entre el negro y blanco, dos puntos extremos que no son colores, sino límites. Entre ellos se desarrolla una gama intermediaria, de prodigiosa riqueza, pero cuyos tonos no es fácil distinguir. Hugo emplea indiferentemente el fusain, la grafita, el lápiz, la tinta china, la tinta ordinaria, el «jus des mures», y generalmente todo lo que tiene a la mano: la sepia, la cebolla quemada, la ceniza de cigarro, el carbón, el negro de humo, el papel quemado, los dentífricos, le sirven para matices preciosos.

«Y esos elementos distintos, lejos de rechazarse al estar juntos, se funden en tintes de un efecto intenso y extraño.

«Es cierto que cuando un poeta se acerca a su mesa de trabajo, tiene intención de escribir obras maestras. Si llega a hacerlo, tanto mejor; y Victor Hugo nunca ha fallado. ¡Pero qué! Cosas semejantes se ven todos los días; un zapatero se sienta delante de su obrador para hacer un par de botas; un general junta sus tropas para conseguir la victoria, y la consigue, a menos que no tenga puentes demasiado cortos para atravesar los ríos; en fin, se han visto gentes con intención de hacer alguna cosa y han salido de su tarea, bien o mal. Pero yo no he oído jamás hablar de un escritor, poseído por la idea de escribir un drama o una novela, y que produzca, sin pensarlo, aguas fuertes involuntarias, no solamente en su prosa y en sus versos, sino en el margen de sus manuscritos, sobre la madera de su buró, sobre las tapas de sus cajas, o sobre los pedazos de papel que le caen bajo su mano.

«El agua-fuerte no basta al ímpetu de ese genio que trasfigura todo lo que toca. La mordedura del ácido nítrico le parece muy dulce; es preciso para comprender hasta dónde va la violencia de su temperamento, ver las esculturas en creux con que ha ilustrado los panneaux de Hauteville-House y de Hauteville-Feerie. Figuraos un artista que tenga por buril ese largo hierro con que se revuelve el fuego de coke, y al cual los ingleses llaman "poker»; con esa barra enrojecida al fuego es que Victor Hugo ahonda en el pino o en la encina líneas llameantes, carbonizadas. Consigue asi efectos prodigiosos. Este grabado incendiario se colora de tintes polícromos, y flores maravillosas se abren, nacidas vivas de la imaginación del poeta.

«Algunos cuadros decorados de esta manera existen en París y dan testimonio de los recursos de este extraño trabajo; pero los más bellos monstruos, las más bellas quimeras que nacieron, quedaron allá en la isla». ${ }^{78}$

${ }^{78}$ El texto traducido por Darío pertenece al volumen de Richard Lesclide, Propos de table de Victor Hugo. Recueillis, Paris, E. Dentu, 1885, 220-222. El nicaragüense retorna a estos conceptos casi una década después, en 1904, al relatar su visita a la casa-museo de Victor Hugo en París: "Ahí está una chimenea decorada por él, orientalmente, y muchedumbre de panneaux coloreados y dorados de modo hábil y pintoresco. Son caprichos de mandarín, visiones chinescas, animales fabulosos, fragmentarias pagodas, inauditos dragones, cómicos personajes del Imperio Celeste, flores raras, juegos decorativos de líneas y de figuras, hecho todo en tablas, uno como pirograbado y policromo, de la más interesante inventiva. Y cuadros y retratos, y más cuadros y más retratos. Sobre todo llama la vista y la 
Siguiendo ese procedimiento del Maestro de los maestros, el señor Pardo de Tavera ha encontrado magnífico campo para su fantasía y para su habilidad.

Necesita para esa clase de obras una mano firme y segura. Tiene que emplear en los valores de tonos, fierros calentados con mayor o menor intensidad, y aplicarlos con un tino que mida la quemadura necesaria, en su propio punto, ni un ápice más, ni un ápice menos. Así os explicaréis los matices, desde el negro del carbón al rojizo de la quemadura ligera, y el color de miel quemada de algunos tonos intermedios.

A la linda rubia de su Ensueño -rubia de senos de niña- ha agregado después el artista colores suplementarios, siendo de muy bonito efecto la ornamentación semijaponesa del ropaje.

En las tapas del álbum el fuego ha hecho solo su obra: son intrincamientos decorativos en la franja que encuadra, en una hoja; en la otra, entre flores y variados motivos ornamentales, una mujer pensativa, con un libro en la mano, bajo un árbol.

Por ambos trabajos merece aplausos el señor Pardo de Tavera.

Asimismo por sus estatuitas en bronce. C'est moi!..., un chicuelo que vive; Un antropófago, un bebé que ugolinea ${ }^{79}$ con su muñeco, sin levantar la boca del fiero pasto; y ¡Pero qué dura!... otro chico que quiere romper una cáscara con los dientes. También presenta el mismo autor la fotografía de otra escultura suya: Croquemitaine. El hombre terror de los chicos, va cargado con una red llena de ellos.

El señor Pardo de Tavera parece tener predilección por los niños; $\mathrm{y}$ en sus temas los trata siempre con gran atención, un bello humor y un buen cariño.

No dejéis de ver en la «Galería» del Salón cuán hermosamente se ha hecho decorar sus Poesías el bibliófilo-poeta Domingo D. Martinto. Sívori ha sido el decorador. ${ }^{80}$ No han podido exponerse todas las acuarelas que ilustran el libro; pero las que están en la vitrina pueden dar idea de las demás. Estamos lejos de ilustraciones al por mayor, trabajos de keepsake, vistosos librotes de año nuevo. Es una labor de refinado que se paga un lírico rico.

Sívori ha interpretado asuntos de casi todas las poesías; ha adornado mayúsculas y ejecutado admirables culs de lampe.

meditación la obra pictórica de Hugo. Habrá un libro muy importante y profundo el día en que un artista pensador escriba el que merecen las concepciones gráficas del altísimo poeta de Francia. Es en los dibujos, es en el Victor Hugo pintor en donde se completa la personalidad portentosa del rimador formidable y profético. Solamente en Turner, en Blake, en ciertas cosas de Piranesi, se percibe la cantidad de ensueño y de misterio que en las visiones manifestadas por Hugo en tales páginas de un «romanticismo» eterno y transcendente". Esta crónica, "Articles de París. Friné. Chez Hugo", fue publicada el 28 de octubre de 1904 en La Nación y compilada en Parisiana (1907).

${ }^{79}$ El curioso neologismo dariano reenvía al célebre episodio de la Divina Comedia de Dante que tiene como protagonista a Ugolino della Gherardesca, en el último círculo del Infierno (cantos XXXII y XXXIII).

${ }^{80}$ Se trata del volumen Poesías. 1880-1894 (Buenos Aires, Jacobo Peuser), de Domingo Martinto (1860-1898), con ilustraciones de Sívori y prólogo de Calixto Oyuela. 
Ved todas las acuarelas expuestas; fijaos sobre todo en La caida de las hojas; en donde, indudablemente recordando a los decoradores ingleses contemporáneos, el artista ha dejado unas lindas hojas otoñales; ved también los motivos foliáceos que adornan La dicha; y el amor que desde una rama florida infla pompas de jabón que el acuarelista irisa. Pero, cuando hayáis mirado todo eso, quedaos un instante, varios instantes, en frente de la Apoteosis soneto del cual dice el impecable Oyuela que es «lleno de plenitud y de vida, como el objeto que lo inspira». ¡Por Verlaine que es portentoso y pleno y vivo ese objeto, oh Sívori! Es la Venus moderna brotando de las espumas de su ropaje; es la divina línea serpentina; es la «Arcilla» de Hugo modelada por un estatuario del placer; es el Triunfo de la Carne, en esa figura que no muestra el rostro, sino la maravillosa euritmia del cuerpo: el descenso de las ondulantes colinas, las redondeces, la lira del talle, la opulencia calipigia, el imperio de la armonía y del amor: ¡la Mujer!

Podéis echar una ojeada por algunos dibujos de la pluma, entre ellos uno de Mayol; podéis ver también la corta sección de negro y blanco, carbones de la señora de Martinto, dibujo de un artista cuya reputación no está por hacerse -Coutell ${ }^{81}$; podéis saludar a la ardiente Graciucha de Ballerini, pintada a la acuarela; podéis aplaudir la afición inteligente de distinguidas damas, y aprobar el delicado retratito en porcelana que presenta la señora Aguirre de Vassilicós ${ }^{82}$; y luego, podéis mirar, en un instante, lo poco de escultura que hay. Ya hemos visto la Bacante de Dresco y los trabajos del señor Pardo de Tavera. ¿Qué más? Una fotografía de la estatua del religioso Santa María de Oro, buena obra que afirma el prestigio de Correa Morales ${ }^{83}$; un bajo relieve -retrato- trabajado con amor y talento por D. M., una dama argentina, según se sabe; un cristo de bazar; Un rasguño, de Mateo Alonso, y una Zerlina, de Arduino. ${ }^{84}$ Lo demás...

Luego, al salir, os atraen las obras de hierro de Wuits ${ }^{85}$, afeadas tan solamente por un cartón de réclame comercial que está junto a ellas. Tienta a ese artesano, a ese artista, la

${ }^{81}$ Posible errata, que dejamos sin corregir. Es factible que la referencia corresponda a Rafael Juan Contell (1850-?), pintor e ilustrador español, fundador y director artístico en 1892 del periódico porteño La Ilustración Sud-Americana.

82 María Josefa Lidia Aguirre de Vassilicós (1838-1913), pionera entre las mujeres argentinas dedicadas a la escultura, se formó en Europa y obtuvo cierto reconocimiento en París a principios de la década de 1890, al exponer obras como "Resignación" y "El genio de Colón señalando su ruta en el océano".

${ }^{83}$ Lucio Correa Morales (1852-1923), el primer escultor argentino de renombre, llevó adelante una vasta producción de obras funerarias, monumentos conmemorativos y decorativos, al tiempo que se dedicó a la enseñanza de la escultura en la Sociedad Estímulo de Bellas Artes.

${ }^{84}$ El listado de escultores se completa con el argentino Mateo Rufino Alonso (18781955) y el italiano Giovanni Arduino (1857-1912), ambos galardonados con " $1{ }^{\circ}$ Mención honrosa de $1^{\circ}$ Clase" en el certamen del segundo Salón del Ateneo (1894).

${ }^{85}$ Nuestra investigación no ha podido identificar a este artista. 
flora del hierro, si hoy olvidada casi, cultivada en lo antiguo por hábiles herreros inspirados, que trenzaban y ornaban las rejas de los claustros y las catedrales.

Buenos trabajos dejaron los viejos españoles y, en lo moderno, algunos escasos ferrófilos conocerán la tradición. El señor Wuits debe de haber visto en Anvers los pilares de la Bolsa.

Juntamente, aplaudid a Giudici ${ }^{86}$, que presenta un ornamento en madera tallada, una cabeza de caballo que termina en tallos vegetales, motivos tomados de las obras de los artistas medioevales, los Jerome Bosch, los Brueghel, los Schongaüer. Artistas que decoren el mueble, que lleven el arte a la industria, que hagan sentir el arte tenazmente al público, son los que faltan.

Y con celebrar el fino trabajo de los camafeos de Negroni ${ }^{87}$, muy griegos y muy bonitos, y con deciros que para hablar de los proyectos del arco del Triunfo de la Reconquista, habría que estudiarlos en artículos especiales; y que las excelentes fotografías de la sala agregada no tienen lugar en la crítica del Salón, me despido de vosotros, lectores, pues ha terminado ya la tarea que me ha encargado la Dirección de LA PRENSA.

RUBÉN DARÍO.

\section{BIBLIOGRAFÍA}

ACEREDA, Alberto.

2003 "Dos visiones del espacio marino como modernidad. Entre la poesía de Rubén Darío y la pintura de Joaquín Sorolla”, Revista de Literatura, vol. LXV, núm. 129, pp. 119-143.

BIBBÓ, Federico.

2014 "El Ateneo (1892-1902). Proyectos, encuentros y polémicas en las encrucijadas de la vida cultural", en Paula Bruno (ed.), Sociabilidades y vida cultural. Buenos Aires, 1860-1930. Bernal: Universidad Nacional de Quilmes, pp. 219-250.

CARESANI, Rodrigo Javier.

2014 "Poetas traductores de la modernidad latinoamericana: de Rubén Darío a Julio Herrera y Reissig”, en Delfina Muschietti (comp.) et al., Traducir poesía. Mapa rítmico, partitura y plataforma flotante. Buenos Aires: Paradiso, pp. 99-121.

${ }^{86}$ Reinaldo Giudici (1853-1921), pintor italiano naturalizado argentino, uno de los principales “educadores" en el contexto de la Sociedad Estímulo de Bellas Artes según la perspectiva de Schiaffino, autor de un óleo decisivo para la historia del arte en el fin de siglo, La sopa de los pobres (1884).

${ }^{87}$ Felipe Negroni (1837-?), artista italiano especializado en camafeos y trabajos en piedra dura, llegó a Buenos Aires en 1884 para fundar un estudio de escultura. 
COLOMBI, Beatriz.

2004 "En torno a Los raros. Darío y su campaña intelectual en Buenos Aires", en Susana Zanetti (ed.), Rubén Dario en La Nación de Buenos Aires (1892-1916). Buenos Aires: Eudeba, pp. 61-82.

COMFORT, Kelly.

2011 European Aestheticism and Spanish American Modernismo. London-New York: Palgrave Macmillan.

DARÍO, Rubén.

1938 Escritos inéditos recogidos de periódicos de Buenos Aires y anotados. Ed. Erwin K. Mapes. Nueva York: Instituto de las Españas en los Estados Unidos.

DORMENT, Richard \& Margaret F. MACDONALD.

1994 James McNeill Whistler. Exhibition Catalogue. London: Tate Gallery.

GABRIELONI, Ana Lía.

2006 "Interpretaciones teóricas y poéticas sobre la relación entre literatura y pintura: breve esbozo histórico del Renacimiento a la Modernidad", Saltana. Revista de literatura y traducción, $\mathrm{n}^{\mathrm{o}} 1$. Disponible en línea: http://www.saltana.org/1/docar/0010.html [Consultado: 16 de noviembre de 2006].

GARcíA Morales, Alfonso.

2004 "Un lugar para el arte. Rubén Darío y Eduardo Schiaffino (documentos y cartas inéditas)", Anales de Literatura Hispanoamericana, núm. 33, pp. 103-173.

2006 "Un artículo desconocido de Rubén Darío: «Mallarmé. Notas para un ensayo futuro»", Anales de Literatura Hispanoamericana, núm. 35, pp. 31-54.

GONZÁlEZ STEPHAN, Beatriz y Jens ANDERMANN.

2006 Galerías del progreso. Museos, exposiciones y cultura visual en América Latina. Buenos Aires: Beatriz Viterbo.

Gramuglio, María Teresa.

2013 Nacionalismo y cosmopolitismo en la literatura argentina. Rosario: Municipal de Rosario.

HEFFERNAN, James W.

1999 "Speaking for Pictures: the Rhetoric of Art Criticism", Word \& Image, vol. 15, nº 1 , pp. 19-33.

LAERA, Alejandra.

2007 "El Ateneo de Buenos Aires. Redes artísticas y culturales en el fin de siglo", en. Américo Castilla (ed.) et al., Primeros modernos en Buenos Aires (1876-1896). Buenos Aires: Museo Nacional de Bellas Artes, pp. 18-25. 
MALOSETTI CostA, Laura.

2001 Los primeros modernos. Arte y sociedad en Buenos Aires a fines del siglo XIX. Buenos Aires: FCE.

2004 “Un Ruskin en Buenos Aires? Rubén Darío y el Salón del Ateneo, en 1895", en Susana Zanetti (ed.), Rubén Darío en La Nación de Buenos Aires (1892-1916). Buenos Aires: Eudeba., pp. 105-121.

2008 "Artistas viajeros en la belle époque", en Cuadros de viaje: artistas argentinos en Europa y Estados Unidos (1880-1910). Buenos Aires: FCE, pp. 13-49.

MONTALDO, Graciela.

2007 "Exhibición, espectáculo y mal gusto: los desórdenes del Modernismo hispanoamericano", Revista de Estudios Hispánicos, $\mathrm{n}^{\circ} 41$, pp. 73-93.

OLIVER BELMÁs, Antonio.

1968 "Los artistas plásticos", en Este otro Rubén Dario. Madrid: Aguilar, pp. 290-319.

PAGANO, José León.

1937 El arte de los argentinos. Buenos Aires: Edición del autor, vol. 1. PIZARRO, Ana.

1994 De ostras y caníbales. Reflexiones sobre la cultura latinoamericana. Santiago de Chile: Universidad de Santiago.

RAMA, Ángel.

1984 La ciudad letrada. Hanover, Nueva Jersey: Ediciones del Norte.

SCHIAFFINO, Eduardo.

1933 La pintura y la escultura en Argentina (1783-1894). Buenos Aires: Edición del autor.

SCHULMAN, Iván A.

2013 "Rubén Darío: pintor", en Rocío Oviedo Pérez de Tudela (ed.), Rubén Darío en su laberinto. Madrid: Verbum, pp. 23-32.

SISKIND, Mariano.

2014 Cosmopolitan Desires. Global Modernity and World Literature in Latin America. Evanston: Northwestern University Press.

TINAJERO, Araceli.

2004 Orientalismo en el modernismo hispanoamericano. Indiana: Purdue University Press.

TORRES, Alejandra.

2014 "Leer y mirar: la apuesta de Rubén Darío como director de revistas ilustradas", en Hanno Ehrlicher y Nanette Rißler-Pipka (eds.), Almacenes de un tiempo en fuga. Revistas culturales en la modernidad hispánica. Aachen: Shaker, pp. 200-210. 
ZANETTI, Susana.

1994 "Modernidad y religación: una perspectiva continental (18801916)", en Ana Pizarro (ed.), América Latina: palavra, literatura e cultura. São Paulo/Campinas: Memoria/Unicamp, vol. 2, pp. 489534.

2004 (ed.) Rubén Dario en La Nación de Buenos Aires (1892-1916). Buenos Aires: Eudeba. 